\title{
PERUANISMOS, OBRA CLÁSICA Y MODERNA
}

\author{
Luis Jaime Cisneros
}

Juan de Arona inició en el Perú una seria, ordenada y científica preocupación por el léxico. Desde entonces, su Diccionario de peruanismos fue modelo y tentación que muchos pretendieron repetir. No ha sido fácil, porque si no lo es ordenar una serie de papeletas lexicográficas, menos lo es, a esta altura de la ciencia filológica, el intento de redactar un diccionario. Una cosa es asignar a cada palabra el significado que la comunidad le reconoce, y otra muy distinta es dedicar ciencia y paciencia a estudiar cómo ha ido adquiriendo cada palabra su vigencia y su significado. Es entonces cuando tenemos que preocuparnos por la antigüedad de los textos; porque si lo que nosotros poseemos del siglo XVI nos permite presumir a los valores fonológicos del sistema toledano tardío como su base fonológica, lo concerniente al destino de los significados y al surgimiento de nuevas acepciones es realmente otro cantar. Al comparar unas palabras con otras podemos ser visitados por una falsa impresión o incurrir en el engaño mismo; necesitamos movernos con cautelosa seguridad en el campo de la etimología para no errar. Porque, como es bien sabido, tanto el sistema semántico, como el formal y como el propio sistema conceptual de la lengua son sistemas en movimiento continuo y viven en influencia mutua " $y$ lo 
que es más grave; si hay evolución en uno de estos planos, esta evolución puede tener repercusiones en los otros" (Baldinger, RFE, XLVIII, 1965, 101). Y como todo léxico es expresión de la sociedad y reflejo de los hechos sociales, una asignación equivocada de significado puede representar una grave malinterpretación. Este es un distingo en que lexicólogos y lexicógrafos tienen puesta la atención, pues nada hay más delicado que moverse en el mundo de los campos semánticos o de los campos conceptuales. Lo dijo con su claridad habitual Otto Duchacék:

Létude des champs sémantiques, ainsi que celle des champs conceptuels, est d'une grande importance pour la lexicologie et pour la lexicographie (conception plus approfondie et plus scientifique des dictionnaires idéologiques). Elle est également de haute portée pour l'identification de la structure du lexique de nos jours ainsi que de n'importe quelle époque littéraire $(V R, 18,1959,500)$

Las sorpresas del lexicólogo son graves y frecuentes; puede darse con voces emparentadas etimológicamente que figuran en campos conceptuales distintos, porque en realidad "un mismo origen etimológico no garantiza la conformidad de las acepciones ni la pertenencia al mismo campo conceptual, y menos aún la pertenencia al mismo grupo" (ibid., 319). La experiencia de que todo vocabulario es insuficiente nos prepara para admitir tropiezos en la práctica de toda comunicación. Todo esto hay que tener presente para entender por qué Peruanismos es un libro clásico y moderno ${ }^{1}$.

Si en el libro dedicado por Martha Hildebrant a la lengua de Bolívar (1962), el sello de la enseñanza de don Angel Rosenblat era una clara marca de la investigación, la escuela del gran maestro argentino luce con solvencia y gallardía

Martha Hildebrant, Peruanismos, Lima, Jaime Campodonico Editor, 3a. ed., 1998, 545 pp. 
desde la primera edición de Peruanismos, en 1969; con ella se reanudó entre nosotros el mismo nivel de solvencia en que Arona había colocado a la preocupación por el lenguaje en el Perú. La Biblioteca Nacional publicó en 1994 una segunda edición, que implicaba una revisión de la primera. El equivocado sistema de difusión y venta malogró realmente ese buen propósito: el libro no circuló debidamente, nunca fue posible adquirirlo en librerías, no mereció una reseña de corte académico. Y no quiero ahora que esta edición finisecular pase inadvertida sin merecer un testimonio universitario de lectura y meditación.

Peruanismos no es un diccionario de provincianismos y no fue nunca la intención de $\mathrm{MH}$ que lo fuese. Es un libro que reúne papeletas lexicográficas, caracterizado por la información técnica y el manejo de un adecuado aparato crítico; una obra de investigación lingüística donde se presentan o se discuten palabras entonces vigentes en el Perú: tropezamos, así, con su historia, sus variantes semánticas, su etimología. Por eso es obra de consulta e información erudita. Es un libro clásico de nuestra bibliografía nacional, imprescindible para quien desee interiorizarse de aspectos importantes de la lexicografía hispanoamericana y, en especial, informarse sobre el vocabulario que estuvo vigente treinta años atrás en el Perú. Y debemos celebrar que la labor parlamentaria no haya alcanzado con sus apremios y sus justificaciones a debilitar la tenacidad con que Martha Hildebrant se ha entregado a la labor cultural; no solamente tenemos testimonios rotundos de ello en la tarea editorial a que ha convocado al Congreso de la República, ni en el ciclo de conferencias magistrales organizado en el seno del antiguo Senado, sino también en las notas periodísticas que sobre temas lingüísticos ofrece periódicamente. Que, consciente de la importancia de este antiguo libro suyo, haya asumido ahora su reedición, constituye un acierto digno de relieve.

El libro difiere en muchos aspectos del de 1969. Aunque la introducción no haya variado, ahora luce títulos orien- 
tadores que la tornan atractiva para quienes, sin ser especialistas, se sienten interesados por asuntos filológicos. Ahora $\mathrm{MH}$ conduce escalonadamente al lector, como en una clase introductoria, hasta llegar al meollo. Así, en primer término, asistimos a la relación entre peruanismo y lengua general; para $\mathrm{MH}$ es peruanismo "todo uso lingüístico -fonético, morfosintáctico, léxico- vigente en el Perú pero excluido del español general". Continúa con el tema de la corrección e incorrección; hoy "podemos lícitamente suponer que lo incorrecto de hoy llegue a ser lo correcto de mañana: la lengua está en continuo fluir y las formas lingüísticas ascienden y descienden socialmente", y no la hace prestigiosa o mejor a una palabra el hecho de que haya nacido en América o España; nacidas en cualquier lugar, lo que asegura a las palabras carta de naturaleza es que surgen y se imponen en el seno del mismo sistema lingüístico. Toda palabra que responda a las posibilidades y realizaciones del sistema pertenece irremediablemente al español. "No hay una mejor lengua - escribía Amado Alonso- sino una lengua de todos y cada uno de nosotros, que sólo entonces adquiere la dignidad de ser mejor, cuando nos integramos en ella y creamos el sistema de sistemas que es el español general". Seguidamente se ocupa MH de los niveles de habla: el de la lengua culta o formal, el de la lengua culta espontánea y el de la lengua popular; y se adelanta a recordarnos "que todo hablante es en realidad plurilingüe, en el sentido de que se expresa alternativamente en diferentes niveles de habla que implican distintas variedades funcionales -situacionales- de su propio idiolecto". Analiza seguidamente los 'tipos de peruanismos' y nos recuerda que el fondo común del llamado español de América "es una variedad de castellano andaluzado que hoy se prefiere llamar español atlántico para incluir la coincidente modalidad canaria". La historia y la evolución de la lengua hablada por nosotros no ha dejado de estar relacionada con la historia y la evolución de la sociedad: "todo cambio operado en el seno español de nuestra vida colonial repercutió necesariamente en el panorama total de la lengua" (Zamora Vicente, NRFH, XIII, 133). Cierra MH su introducción presen- 
tando las características fonéticas, morfosintácticas y léxicas del vocabulario hispanoamericano. Una buena disposición gráfica hace amable el acercamiento inicial.

Esa es la novedad primera de la edición. Una segunda novedad: la ordenación alfabética del material obedece a las nuevas reglas de la Real Academia Española, que son felizmente la de la ordenación latina consagrada en el Diccionario de Autoridades, el primero de la institución, y que ha sido la ordenación mantenida en toda la tradición lexicográfica. Es decir, no hay apartado para la /ch/ ni lo hay para la /11/; por lo tanto, cebiche aparece antes de chafalonía y cimarrón se lee inmediatamente después de chupo. Y por supuesto más tarde tendremos palangana, y antes de palomilla habremos tropezado con pallar.

Una descripción demorada nos permitirá puntualizar otros pormenores de esta nueva edición. Martha Hildebrant celebra que la Real Academia Española haya acogido en su Diccionario de 1992 las etimologías por ella propuestas en 1969 para cebiche (p. 104) y tocuyo (p. 414). Ha preferido ceder a fustán el título de la papeleta léxica que en el 69 había concedido a fuste, sin duda influida por la fuerza del uso. Se recogen las aclaraciones que el DRAE ha formulado en ediciones posteriores a 1969 sobre las voces siguientes: acápite, aguaitar (MH ha modificado la redacción primitiva), atingencia (MH formula algunas distancias con el DRAE), canillita, carátula, cardumen, chance, chau, chequear, chivillo, chompa, chupo, chusco, conscripción, coto, cuja, encomienda, extrañar, forado, fungir ( $\mathrm{MH}$ lo cataloga dentro de los latinismos de América), hambruna, laja, lunarejo, macana, petate, pifiar, playa, ponérsele, prolijo, prosa, pucho, punta (MH agrega comentarios a observaciones de F. Lázaro Carreter), quiñar, rajar, rangalido ( $\mathrm{MH}$ confronta con el Diccionario Vox), recién, refundir, remezón, requintar, tongo, trapiche, tutuma, uta, vincha, yapa, zamaquear y zapallo. 
Pero no solamente estos alcances al DRAE contiene la edición. Martha Hildebrant ha establecido una nueva redacción para varias papeletas (por ejemplo: anchoveta, camal, cardumen, conscripción, zonzo): ha agregado o suprimido información en otras, como en baja policía, baquiano, botar (donde agrega lo relativo a botar el gato 'vomitar'), cabulear (ahora ha suprimido su conjetura de desarrollos paralelos, que en 1969 ofrecía como dudosa), caporal, (con interesantes adiciones), carrera, codear y concho (realzado por útiles agregados). Hay adiciones significativas en las papeletas alusivas a disticoso, frazada, fustán, gago, huachafo, lisura, macana, montonera, muñecos, no más (con datos mexicanos y argentinos que enriquecen la información), palangana, parar (una simpática alusión a 'parar los machos'), pechuga, pisco (con datos para mejorar el sabor), poncho ( $\mathrm{MH}$ acepta ahora la tesis de Morínigo, de la que ya dudaba en 1969), pucho, rancho, raza, trome, yaya, yuyo, zambo. Dos erratas para salvar: s.v. lunarejo (p. 255, línea 1) debe leerse XVII y no XVI; s.v. raza (p. 376, línea 21) deberá leerse fusión, como en la ed. de 1969, y no confusión.

Libro fundamental éste de Martha Hidebrant, que no ha perdido trascendencia. Se nos ofrece en él una selección de voces cuya historia y etimología se estudia y se discute, y donde toda opinión es fruto de investigación y análisis: "lo importante, en etimología, decía Harri Meier, es la discusión entre opiniones y propuestas diversas" (Verba, 14, 1987). Una obra de esta naturaleza hurga en ejemplos de la literatura y del habla coloquial, busca reconstruir la historia del uso de las palabras, arriesga etimologías; y es por eso por lo que, como todo trabajo lexicográfico, nace siempre en procura de adiciones, confirmaciones o rectificaciones, juego gracias al cual garantizamos el progreso de los estudios lexicográficos. Ese sentido tienen las propuestas con que, a continuación quiero de alguna manera realzar y enriquecer la evidente aportación que Peruanismos representa en el campo de la filología hispánica. En esta exposición procuro únicamente enriquecer la información lexicográfica y, por cierto, sólo entro 
a analizar etimologías cuando juzgo que el análisis puede tener valor aclaratorio. Resulta para mí interesante la confrontación con algunos antiguos diccionarios; entre aquellos con que trabajo los hay etimológicos, así como otros bilingües, que tuvieron importancia en su momento porque acogían muchas de las voces que tenían prestigio americano y así lo consignaban; cotejar entre sí algunos de ellos nos permite aclarar (o conjeturar) la época en que algunos usos comienzan a alcanzar vigencia y prestigio al tiempo que difusión internacional. Me interesa plantearme (y en seguida indagar las razones) por qué si un diccionario base del español deja constancia del origen o de los usos americanos mismos, algunos famosos diccionarios extranjeros no siempre se sienten interesados en consignar el hecho ${ }^{2}$. Un caso ilustrativo es camote; en tanto que el diccionario español aclara su origen y uso americano, muchos de los extranjeros lo omiten: así tenemos Oudin (1607), Vittori (1609) y Minshev (1617) se limitan a registrar batata, y sólo en la explicación de batata aluden a América. A este respecto resulta significativa la información que ofrece Sejournant en 1775; no registra camote sino únicamente batata, a la que dedica una curiosa explicación, diferente de la que ofrecen otros diccionarios: explica que con la batata se hacen dulces y la califica como alimento de negros. Otro caso interesante es ciertamente el de chapetón. Así, para Peñalver, "en el Perú, es el europeo", para Sejournant se trata del "nom qui donnent les mexicains aux européens \& aux espagnols qui arrivent pauvres chez eux". En cambio, en los diccionarios extranjeros del XVII no hay alusión alguna a América a propósito de esta voz: Palet (1604) consigna solamente nouveau; Oudin (1607), nouveau; Minshev (1617), novitius. Los del XVIII, tanto españoles como extranjeros, dan noticia, aunque confusa, relacionada con América. Y no deja

2. Esto propone una investigación de otra índole, ajena a los propósitos de este artículo. Debe tenerse en cuenta que no todos los diccionarios bilingües responden a un mismo propósito. Cf. Kurt Baldinger, Semasiologie und Onomasiologie in zweisprachigen Wörterbuch (Fest. Wandruska, Tübingen, 1971, 384-396) 
de ser entretenido comprobar con qué esclarecida inocencia muchos de los autores que aluden a 'las Indias' las ubican imprecisamente en América, y a veces en China y aun en Turquía.

En mi exposición acogeré datos de los siguientes diccionarios: M. de Sejournant, Nouveau dictionnnaire espagnolfrançois \& latin, Paris, Chez Ch. Antoine Jombert, 1775; Leopoldo de Eguilaz, Glosario etimológico de las palabras españolas, Granada, 1886; Antonio Martín de Heredia, Tesauro de Requejo Reformado, Madrid, Fuentembra, 1828; Juan Peñalver, Pan-léxico. Diccionario universal de la lengua española, 2 vols. Madrid, 1882; Eduardo de Echegaray, Diccionario general etimológico de la lengua española, 4 vols. Madrid, Paquineto-Alvarez Impresores, 1887-1888; Aniceto de Pagés, Gran diccionario de la lengua española, 5 vols. Madrid, Sucesores de Rivadeneyra, 1902: Real Academia Española, Diccionario histórico de la lengua española, 2 vols. (A-C), Madrid, 1933-1936; Georg Friederici, Amerikanische Wörterbuch, Hamburg, De Gruyter, 1947. Utilizo además algunos léxicos extranjeros del XVI y el XVII cuando juzgo oportuna la confrontación, y en tales casos me acojo al Tesoro Lexicográfico de Samuel Gili Gaya, al que me remito para la respectiva identificación ${ }^{3}$.

3. Para la apreciación de los distintos diccionarios en los siglos XVIII hasta la fecha, cf. Günther Haensch, Los diccionarios del español en el umbral del siglo XXI, Ed. Universidad de Salamanca, 1997. No he podido ver la ed. facsimilar que preparó Manuel Alvar de Esteban de Terreros y Pando, Diccionario castellano con las voces de ciencias y artes, 4 vols. Madrid, 1786 (Arco Libros, 1987). Ni he logrado consultar en Lima Lamine Benaller, Dictionnaire des hispanismes dans le parler de l'Oranie, Alger, 1992; Cristóbal Corrales et alia, Tesoro lexicográfico del español de Canarias, Madrid, 1992; Manuel José de Ayala, Diccionario de voces americanas, siglo XVIII, Madrid, Arco Libros, 1995. He revisado someramente en una semana María Schwaiss, Lateinamerikanisches Spanisch, 2 vols. Leipzig, 1977. 
ACOMEDIRSE. El Diccionario Histórico (en adelante DH) lo registra como americanismo y define así:

"Prestarse espontánea y graciosamente a hacer un servicio". El participio acomedido alude a una persona servicial, oficiosa, y muchos lexicógrafos lo consideran también como americanismo. Moreno de Alba piensa (s.v. acomedido) en dos fenómenos simultáneos concurrentes: morfológico uno (con antecedentes en otros arcaísmos), y semántico el otro, "en que se añade un nuevo sentido a los varios con que cuenta el verbo comedir(se)" (J. Moreno de Alba, Minucias del lenguaje, FCE, México, 1995)

AGUAITAR. Nebrija en su Vocabulario, 1942, la da como 'assechar'; y al explicar aguaitamiento expresa: captatio insidiae. Entre las voces medievales recogidas en el Glosario de Toledo podemos leer: insidia 'assechanza'. Peñalver la registra con el valor de 'acechar', 'atisbar' y acoge asimismo aguaitador y aguatamiento, que ya aparecían en 1611 en Covarrubias. Con idénticos valores, y reivindicándolos como del ant. esp. la acoge Eusebio Castex en sus Tópicos lexicográficos, Bs. As. 1927. El DH no agrega nada, como no sea la fecha de 1527. Pagés repite a Echegaray y cita a Orozco y a Covarrubias, pero aventura que se deriva del ant. al. Wathan 'acechanza', 'emboscada' y arriesga comparaciones con el it. agguata 'acechar's . Con datos y textos de Rosenblat recuerda Isaías Lerner las significaciones de 'morar', 'ver', 'esperar' (Arcaísmos léx. del esp. de América, Madrid, Ínsula, 1974). Lo importante acá es el vínculo establecido por Vicente García de Diego con el and. aciguatar (RFE, XVIII, 1931, 1-6); precisa VGD que aciguatar ('atisbar', 'acechar') revela la exis-

4. En los diccionarios bilingües del XVII hay cierta confusión entre acechar y assechar: así Oudin (1607) traduce assechar por 'espier', 'guetter', pero en acechar remite a assechar. Palet (1604) da guetter como equivalente de acechar, para la que Franciosini (1620) da asimismo spiare. Assechar se ve traducido en Percival (1599) por "to lie in wait". 
tencia del verbo aguatar, emparentado con "goaitar, aguaitar del ant. navarro y el goaita vascuence". El vasc. significa 'acecho', de donde, para García de Diego, "aciguatar es, pues, una superposición" al parecer relativamente reciente de 'acechar' y de aguatar, de wanta ('guarda'). Spitzer (ibid.,235236) se muestra disconforme con este cruce de sinónimos propuesto y recuerda que en Murcia aciguaitar significa "fijar con fuerza, para que no se escape"; de donde vale 'fijar la vista', y por lo tanto, 'perseguir con la mirada', 'captar'. Lo cierto es que para hurgar en la etimología todavía seguirán siendo de utilidad las observaciones de Styff, "Étude sur l'évolution de radical ward dans les langues romanes" ( $Z R P h$, XLV, 630-633)

ANTIER. En Nebrija aparece registrada como adv.: nudius tertius. Para Echegaray se trata de un adverbio de tiempo sincopado de anteayer. Pagés consigna anteayer, con citas de Horozco y Covarrubias. El DH la admite como forma familiar por anteayer. García de Diego (RFE, VII, 145) no la acepta como reducción de anteayer sino como un compuesto de ante heri. Oudin traduce directamente: anteayer.

ARRANCHAR. Echegaray propone una línea etimológica desde el cat. arranjar, prov. arengar, arrengar, arrenjar; fr. XII arenger, arranger, fr. med. arranger (s. XII). La discusión continúa. Delfín Garasa pone de relieve la acepción marinera: "cazar mucho una vela o escota", "ceñir mucho el aparejo", que es casi una paráfrasis de la explicación de Echegaray. Y frente a la explicación de Arona sobre el empleo de la palabra en el Perú, "arrebatar el sentido peruano no coincide con el marino", él advierte que en ambos usos se alude "a un tironeo violento o forcejeo de algo" (Fil. IV, 178-179). La explicación deja ciertamente muchos hilos sueltos. Germán de Granda ha llamado la atención sobre que "se emplea, como hispanismo, en guaraní paraguayo en la forma arranchá/aranchá con la significación de "establecerse, asentarse en algún lugar" (Sociedad, historia y lengua en el Paraguay, Bogotá Inst. Caro y Cuervo, 1988, 321) 
AZAREARSE. Pagés da como equivalentes 'sobresaltarse', 'alarmarse'. El DH la registra para Chile y Perú con el valor de 'irritarse', 'enfadarse'. Cuervo (Apunt. № 587) estudió los casos de azorarse y azararse, voces antiguas de origen cinegético, y la opinión de Covarrubias sigue siendo un buen punto de partida. Clavería ha recordado (RFE, XXXIII, 149, 155-162) cómo puede la etimología popular asociar las voces azorar de "uso más frecuente que azor, pero sin que su significación de 'desgracia impensada' e 'inquietud' o recelo causado por un mal presentimiento "tuvieran que intervenir necesariamente en la asociación". Otro derivado de azar y no de azor, azarearse, se emplea con el mismo significado de azararse en algunos países de América ${ }^{5}$. Clavería da la razón al $\mathrm{DH}$, que tiene a azarar por variante de azorar y rechaza la tesis de Cuervo, que deriva azararse de azar. A fines del XIX, estar acharado era 'estar tristísimo' o 'atontado', y así lo registra A. de Castro en sus Estudios Prácticos de bien decir y de arcanidad del habla española (Cádiz, 1880, apud Clavería, 157). Cf. alhasarear 'hechizar', 'confundir' (cf. embrujar), Cynthia Crews, VR, XIV, 299-300.

BAQUIANO. Echegaray presenta a la voz como americanismo y ofrece tres acepciones:

"Práctico conocedor de un terreno y que sirve de guía para transitarlo"; como uso adj. metaf.: "diestro, experimentado". Seguidamente (s.v. baquiana) nos dice "nombre que dan en Panamá a la mula hecha al trabajo". Y termina aludiendo a un uso metáforico americano: "Mujer astuta, experta, maliciosa", significación que no debe ser contemporánea de su Diccionario porque cuando Oudin explica baquiana (1607) dice escuetamente: "rusée, fine, madrée, experte dessalée". A fines del XVIII, el Diccionario de Terreros tiene

5. Así registra todavía su uso en el Ecuador, donde ya era forma censurada en 1874 por Ríofrío. C. J. Córdova (El habla del Ecuador, 2 vols. Cuenca, 1995. s.v.) 
a baqueano como equivalente de "cursado, inteligente en alguna cosa". Alcedo en su Vocabulario de 1789, consignará una definición que luego hará historia en la lexicografía hispanoamericana: "Práctico de los caminos, trochas y atajos de algún paraje". Baquiano, baqueano y baquía eran para Daniel Granada voces "desde antiguo usadas en Sto. Domigo, Méjico, Guatemala, Nueva Granada y Río de la Plata" y reclamaba para ellas, desde su Vocabulario rioplatense (1889) derecho a aparecer registradas en el diccionario de la academia madrileña. Ya entonces defendía Granada una clara procedencia de baquía y le asignaba a baquiano hasta tres campos semánticos claros y distintos: baquiano era, así: a) "el que conoce prácticamente la campaña o una región cualquiera"; b) "el que por práctica es hábil y diestro en las cosas particulares, los usos y costumbres del país" y, por último, c) "el que es práctico en la navegación de los ríos". Califica seguidamente a baquiano como voz exclusiva del ámbito rural y tiene por preferible a la forma baqueano, aunque agrega seguidamente: "Baquiano es, sin embargo, la derivación legítima del radical de que procede, que es baquía, voz significativa de antigüedad y experiencia"6. Pagés registra la palabra, sin alusión alguna a América, como "práctico de los caminos, trochas y atajos. Guía para poder transitar en ellos". En realidad repite a Alcedo. $\mathrm{El} \mathrm{DH}$, que la inscribe como adjetivo y se autoriza con Garcilaso, acoge solamente dos acepciones: a) "Práctico de los terrenos y caminos de un país, dicho especialmente de los soldados veteranos que en las conquistas de las Indias iban de guías de la expedición" y se ampara en el célebre pasaje de Gutiérrez de Santa Clara (1544); y b) "Ve-

6. En seguida califica de redundante el giro baquiano y muy diestro en la tierra, expresión que atribuye a Bernardo Vargas Machuca "en la Apol. y dis. de las In. Occ.". Granada está citando ciertamente de memoria y confunde la Milicia y descripción de las Indias Occidentales, Madrid, 1599, en cuyo Lib. II puede efectivamente leerse: "y si fuere posible sea toda gente diestra y baquiana". (Cito por ed. Madrid, 1892, vol. 2. p. 115); de hecho, en la final Declaración de nombres propios que cierra el libro original, se lee (s.v. baquiano): "es la gente diestra de la tierra". 
terano o viejo de un país y conocedor de su vida y costumbres", y ofrece testimonios del Guzmán de Alfarache. Pagés incorpora y califica de americanismo a baquía con el valor de 'habilidad' y 'destreza', significaciones recordadas por Lerner en sus Arcaísmos. Para Calcaño (El cast. en Venezuela, № 633) "el americanismo baquía en el sentido de 'conocimiento práctico de los campos' es posterior a baqueano o baquiano y deriva naturalmente de éste". Conjetura luego una procedencia vascuence y arriesga otras discutibles y olvidables etimologías para concluir con esta afirmación "No me parece que haya lógica en derivar baquiano o baqueano de baquía". Grave error suyo. Alvar, que registra también vaquiano, ofrece esta lectura: "Versado en las cosas y tratos de las Indias como son los que han estado algún tiempo en ellas y saben todos los modos cómo se vive en ellas". Y agrega muy rica información con textos de Acosta, Oviedo, Pedro Simón, Juan de Villagutiérrez.

Los problemas de baquiano no solamente se relacionan con su significado sino, como vemos, también con su etimología. A partir de 1925, el DRAE defiende la etimología de baquía "experto, cursado" que es en realidad la definición de Terreros. Hasta entonces tampoco registraba baquía el léxico oficial. Henríquez Ureña le había asignado origen taíno como a batea, cacique, tuna y yuca (RFE, XXII, 175 n.1) y hasta había calificado de curiosidad el que siguiera usándose en América del Sur mientras estaba olvidada "en su lugar de origen" (BDH, V, 125). Hoy nos enfrentamos a dos corrientes: la que defiende el origen arahuaco, en cuya lengua significaba 'guía', y la patrocinada por Corominas (DCELC) que defiende el and. baquía, procedente del árabe baqiya 'residuos', 'resto'? Según Testimonio de Boyd-Bowmann un texto vinculado con Cuba nos ofrece en 1521 la más antigua forma co-

Boyd-Bowmann ofrece la documentación en su Lexico hispanoamericano del s. XVI, Londres, 1971. 
nocida de baquía de que haya noticia. El texto es ciertamente anterior en veinte años a 1544, defendida para baquía, y dice: "yo me he bien informado de personas de baquía e a la sazón eran aquí". Los argumentos de Corominas se fundan en textos del XVI y tienen a baquía por voz de Santo Domingo. Otros, como el padre Acosta, postulan la oriundez de Cuba o Haití, y otros, en tanto, como el Inca Garcilaso, la tienen por palabra procedente "de los barloventanos". José Luis Rivarola asume con nuevos criterios el tema en 1985: su más fuerte argumento en favor de la hipótesis antillana "es la rapidez y la amplitud de la difusión de baquiano, usado en casi toda la América hispana". La amplia difusión de los tahinismos es más importante y representativa, pues no llegaron a alcanzarla ni el nahuatl ni el quechua. A Rivarola se le hace claro, si atendemos al sufijo, que baquía debió de haber sido "originariamente un topónimo o un nombre común de lugar" del que podían probablemente haberse derivado de modo natural un adjetivo en -ano con el significado de 'procedente de', 'propio de'. De ahí es siempre fácil colegir los significados de 'conocedor', 'experimentado' ( $Z R P h, 101,45-51)$. Es relevante para Rivarola el hecho de que el sufijo -ano "tiene como función predominante la formación de adjetivos que indiquen origen, procedencia o también pertenencia, a partir de topónimos o de nombres comunes de lugares" (ibid., 47). Dicho sufijo se hallaba en plena vitalidad a la hora del descubrimiento y conquista de América, y no es de extrañar verlo aplicado a una voz no romance. Para Rivarola, baquiano sí puede proceder de baquía, pero nunca ésta de aquella otra; que baquía se hubiera formado de baquiano, como se pretende, no permitiría imaginar "un proceso de motivación semántica igualmente plausible"

Que Corominas se mantuviera fiel a su tesis del étimo árabe no implicaba un rechazo tajante de la posibilidad antillana: tal vez "el americanismo fue en su origen una voz andaluza de ascendencia árabe, que en el Nuevo Mundo desarrolló un significado nuevo" (DECH. s.v. baquía). Pero no hay testimonio de baquía fuera de América y menos con el 
significado que venimos analizando. En cambio, Rivarola observa la presencia de albaquía en Nebrija como término del vocabulario económico, con el significado de "resto de una deuda". Albaquía está, así, documentada en la Península, en tanto que baquía se halla sólo en textos americanos. Y Rivarola cita un texto sepulvedano del siglo XIII del que reproduzco un fragmento ilustrativo donde luce albaquía con su significación de índole económica:
A lo que me pedieron merçet en razón de las cuen- tas e de las albaquías que dan al mío tesorero, de los míos pechos e derechos que por mi recaudan, en grandes cuantías de moravedís"9 (Colec. Diplomáti- ca de Sepúlveda, I, Segovia, 1956)

El uso peninsular de este término en plena Edad Media obliga a Rivarola a replantear, años después, la tesis de Corominas. Y en 1988 (ZRPh, 104, 419-421) reconoce que su contribución anterior "adolecía de una incómoda laguna en relación con la plausibilidad de la hipótesis americana" y propone entonces "una posible base taína", al tiempo que recuerda que varios de los testimonios aducidos establecen (bien de modo directo, o bien indirecto) "una relación entre

8. Baqija esp. cat. ant. albaquía "residuo o resto de alguna cuenta que queda sin pagar, frente a cat. ant. albaquella (Arnald Steiger, Contribución a la fonética hispanoárabe, RFE, Anejo XVII, Madrid, 1932, 341). Echegaray tiene a albaquía por femenino, anticuado y la vincula además con la recaudación de diezmos de algunos obispados, el remanente o residuo en el prorrateo. Sejournant consigna: albaquia: "vieux mot arabe. Restant d'une compte, Lat reliquia". Palet (1604) explica: "dette pour recouvrer y Oudin (1607): "Les reliques d'une dette à recouvrer".

9. Otros testimonios: la usan también el Marqués de Santillana, aludiendo al hecho de no pagar una cuenta (Poesías, ed. Durán, 165) y Castillejo (Fontecha, s.v.) Eguilaz (Glosario, s.v.) la recoge con el valor de "resto y cuenta" y recuerda las acepciones en Raimundo Martín (Vocabulario en arábico (Firenze, 1871) y 'restante' en el Vocabulario arábigo de P. de Alxalá, 1505. 
baquiano e isleño", ya que los hombres experimentados en asuntos de la tierra "eran los hombres que habían estado desde la primera hora en las islas y eran, por lo tanto, antiguos y experimentados en ellas". Cree ahora en la necesidad de "pensar que el mismo étimo árabe dio lugar a otra forma sin el artículo aglutinado y con un significado más general". Todo va contrariamente a cuanto sabemos sobre préstamos árabes, que pasaron con el artículo aglutinado, y ahora nos vemos en "la dificultad de explicar el doblete baquía/albaquía, tanto por consideraciones semánticas como de orden morfológico relativas a la introducción de préstamos árabes al español". Para Rivarola, baquía puede relacionarse con palabras que en lenguas arahuacas de las Antillas significaron 'isla', de donde la relación baquiano/isleño; después de todo, directa o indirectamente los testimonios del XVI atribuyen baquiano a las Antillas y destacan su vínculo con isleño ${ }^{10}$.

Realmente hemos avanzado en la investigación, pero no hemos progresado mucho en cuanto a la etimología, y es verdad que nadie ha examinado la probable relación del tema con vadicarse (REW 9118) sugerida por Harri Meier (Verba, 14, 1987: Nuevas Anotaciones al DECH). El tema se halla en su mejor momento y la bibliografía creciente en torno del español atlántico, así como la relativa a las lenguas indígenas americanas, invita a profundizar la investigación ${ }^{11}$.

10. Podría confirmar su hipótesis el siguiente pasaje de Pedro de Aguado en su Historia de Venezuela, 1581: "El Esteban Martín era hombre baquiano en las Indias, que es lo mismo que isleño y de experiencia suficiente" (Cito por ed. Caracas, 1913, tomo I, 140). Y quizá convenga recordar que el padre Acosta daba a las palabras chicha, vaquiano y chapetón procedentes "de los isleños de Santo Domingo o Cuba" (Lib. V, cap. 13, 1590)

11. Cito como ejemplos los estudios dedicados a las lenguas arahuacas y a las que tratan las relaciones del taíno con el caribe peninsular (Thes. XXXVIII, 2, 233-254; XLI, 1-2-3, 1-22) y el provechoso trabajo de $\mathrm{H}$. Mejías, Préstamos de lenguas indigenas al español americano del s. XVIII (México, 1980) 
Rolando Laguarda objetó, hace ya algunas décadas, el étimo de Corominas (BAAL, XXVI, 1961, 65-104); partía de que el primitivo significado de baquía 'viejo y veterano' "no encerraba ningún concepto de resto o residuo". Vale la pena retomar algunos puntos de su extensa argumentación. Por cierto, no es la suya excusa fundamental para explicar un cambio semántico, aparte de que un escarceo por campos conceptuales podría llevarnos a admitir que las cosas 'viejas' son testimonio de algo que ha tenido existencia, de cuya veteranía puede dar testimonio. Y esto, sin ánimo de discutir acá los argumentos de Laguarda al respecto. En realidad, a él le interesó llamar la atención sobre algunos asuntos específicos: la presencia de la palabra en el DRAE, los textos que han servido para postular a baquía como base etimológica.

Sinteticemos acá su posición. La Academia acoge en su léxico baquiano y asume en buena parte la explicación de Alcedo. En 1914, el DRAE trae baqueano y nos remite a baquiano; esa incorporación denuncia la existencia de un conflicto ortográfico, y la DRAE sugiere la etimología latina vacanius 'habituado, práctico'. En 1925 Cuervo consagra la etim. de baquía conjeturada por Arona, Gagini y Granada: el texto de Fernández de Oviedo es desde entonces obligado caballito de batalla: "los pobladores que acá llaman de baquía, que quiere decir viejos e veteranos" (Hist. Gral. de las Indias, Lib. XXIX, cap. 33, № xxvii). La Academia Española acoge y defiende desde entonces la procedencia de baquía y Corominas la explica y consagra en su obra monumental. A Laguarda le interesa precisar un detalle: como Fernández de Oviedo escribe en Sto. Domingo, acá quiere decir 'esta isla'. Seguidamente se empeña en comprobar las documentaciones primeras de baquiano:

a) en una relación geográfica de 1579 de una antigua ciudad colombiana podemos leer: "no hallando pues los yndios [...] la defensa que hasta allí en los baquianos que así les llaman a los acá antiguos hallaban cobraron tanto ánimo"; 
b) en 1586, en la versión que Juan de Guzmán hizo de las Geórgicas puede leerse esta nota aclaratoria: "los baquianos que así se les llaman a los acá antiguos"12;

c) en 1589, Juan de Castellanos evoca, ya anciano, cómo se extinguieron los indios en la Española. Y así leemos en las Elegías, canto IV, vs. 529-534:

Los pobres baquianos que vivimos

530 todas questas cosas contemplamos y recordándonos de lo que vimos y como nada queda que veamos con gran dolor lloramos y gemimos con gran dolor gemimos y lloramos.

Claro se está (atentos al texto de Castellanos) que los baquianos acá aludidos son los que, versos atrás, han sido presentados de este modo:

$\mathrm{Y}$ ansí fue que los hombres que vinieron en los primeros años fueron tales

515 que sin refrenamiento consumieron innumerables indios naturales [...]

Lamentan los más duros corazones, en islas tan ad plenus abastadas, de ver que de millones de millones ya no se hallan rastros ni pisadas;

525 y que tan conocidas poblaciones estén todas barridas y asoladas y destos no quedar hombre viviente que como cosa propia lo lamente

12. El mismo Juan de Guzmán insiste luego: "deste mesma isla salieron otros vocablos que están repartidos por las Indias, los quales aunque son usados de nuestros Españoles, no saben los mesmos nuestros que acca están de donde fueron aquellos vocablos sino son algunos curiosos [...] vaquiano que quiere decir cosa antigua" 
Esos hombres recordados en los vs. 513 y 514 son "los primeros pobladores antiguos" a que se aluden en otros textos. Y es verdad, como quiere Laguarda, que en los tres textos citados baquiano significa "viejo, antiguo en la tierra". Pero es en el texto de Castellanos, colocado ahora en su verdadera situación significativa, donde comprobamos en qué medida se juntan en la palabra estudiada las varias significaciones que la tradición acoge (entre ellas, la rechazada por Laguarda), pues, si seguimos atentamente el texto de Castellanos, estos baquianos del v. 529 fueron testigos de los que en "los primeros años" del descubrimiento (v. 514) fueron responsables de la matanza de los indígenas; tienen así, por viejos, acumulados recuerdos en la memoria; por antiguos en la tierra, son experimentados en asuntos que miran a su historia. Estos baquianos son "lo que queda, lo restante" de aquellos pobladores primeros y, por tales, pueden dar fe de lo ocurrido pues, al fin y al cabo, son 'expertos en antiguedades'.

Intenta seguidamente Laguarda propiciar una interpretación de la expresión poblador de baquía, para lo que se remonta a los repartimientos de indios hasta detenerse en una información del geográfo Juan López de Velasco, de quien lo seduce un fragmento donde se explica que divídense los espanoles de aquellas partes en conquistadores que son los que se hallaron en la conquista y pacificación de la tierra y primeros pobladores que todos están mandados preferir en los repartimientos de indios cuando se proveen de nuevo o vacan y en los oficios y aprovechamiento de la tierra, primero los conquistadores y después los pobladores" (BAAL, XXVI, 79-80).

Esta lectura promueve en Laguarda una reflexión que desemboca en la propuesta del lat. vacuus, discusión que no conviene a mi propósito iniciar en este lugar.

El otro aspecto de la argumentación de Laguarda mira al episodio narrado por Pedro Pizarro sobre un entredicho entre su hermano Hernando y Diego de Almagro. Aunque es verdad que la crónica de marras terminó de escribirse en 
1572 , los hechos que acá se mencionan (y es lo que interesa a Laguarda) se sitúan hacia 1530. El asunto es el siguiente: Almagro había prometido proporcionar un par de caballos a dos escuderos de Hernando, "y le dava su palabra de hazello, la qual palabra nunca cumplió, y por esta causa Hernando Piçarro trató mal de palabra a Don Diego de Almagro, llamándole de vaquiano, y dámele vaquiano y dártelo e bellaco, y otras palabras afrentosas" (énfasis mío) ${ }^{13}$.

Bellaco tenía por entonces una significación de 'ruin' y era ciertamente voz ofensiva. Nebrija la explica como inhonestus. Cervantes inicia con esta palabra una graduación de insultos: "bellaco, desalmado, facineroso e incorregible" (Rinconete, RAE, IV, 78 vto.). En un pasaje del Tratado del descubrimiento de las Indias, cap. XV, Suárez de Peralta recuerda un diálogo en que Moctezuma fue insultado de esta manera: "Calla, bellaco, gallina, puto, que por cobarde y por miedo has vendido tu reino y señorío a los españoles" (ed. cit. p. 65). El DH consigna: "malo, ruin, pícaro y astuto refiriéndose a personas o a sus actos y cualidades". Del texto de Pizarro podría desprenderse que el "mal trato de palabra" alude al tono empleado por Hernando y que las "otras palabras" no se consignan precisamente por afrentosas. Puede también admitirse, tal como Laguarda lo ha entendido, que baquiano cargaba por la época (repito: hacia 1530) con una significación ofensiva hasta hoy no documentada fehacientemente. Finalmente, vale la pena estudiar la posibilidad de un uso familiar y metafórico, cargado de malicia e ironía, donde no se elogiaría 'el saber' y 'la habilidad' como virtud sino como un entrenamiento avezado en el pérfido uso $^{14}$.

BATEA. En tanto que Oudin, 1607, se limita a registrar:

13. Relación del descub. y conquista de los reinos del Perú, Cap. III, fol 6/ vto/7. Cito por ed. Univ. Católica del Perú, Lima, al cuidado de Gmo. Lohmann Villena, 1978

14. Cf las variantes negativas actuales de sabido, experto, sabio. Laguarda no ofrece documentación sobre este posible matiz semántico de baquiano. 
"batoir à lessive", puede leerse en Sejournant: "Plateau des Indes ou de Chine, qui est d'un bois vernissé \& peint, sur lequel on arrange les tasses à café". Pero Muñiz, en su Vocabulario rioplatense (1845-46) desarrolla esta minuciosa explicación: "trozo de madera ligera con sus dimensiones regul(ares) de 6 y 8 c(odos) de largo,-media vara de ancho y un palmo de alto- que sirve ahuecado en su mayor longitud, para lavar la ropa -la que se golpea sobre dos testeras lisas que se dejan a sus estremos. Las batanas mayores sirven para tomar la masa para hacer pan" $(B A A L, \mathrm{~V}, 1937,425)^{15}$. Pagés solamente consigna "artesilla honda que sirve para varios usos" y respalda su explicación con citas del Padre Acosta. El DH, en segunda acepción: "Dornajo, artesilla o barreño" y se autoriza con textos de Las Casas, Cervantes de Salazar, el Padre Acosta y Cobo.

BARCHILÓN. Entre 1563 y 1565, el sacerdote español Pedro de Quiroga escribió Coloquios de la verdad, diálogos que tratan de la entrada y conquista de los españoles en el Perú ${ }^{16}$. Barchilón es en la obra un baquiano andaluz que da consejos a un chapetón llamado Justino y conversa con los indios Tito y Cayo. En el estudio a que aludimos en nota se explica que Pedro Hernández Barchilón "pizarrista condenado a muerte por La Gasca después de la batalla de Xaquixahuana, huido y entregado a la vida eremítica durante la cual se preocupaba por la evangelización de los indios y, por los años de la redacción de la obra en Quiroga, administrador del Hospital de Indios de Huamanga". Pagés, inspirado en Pal-

15. Cf. Milciades A. Vignati, El Vocabulario rioplatense de Francisco Javier Muñiz (BAAL, V, 1937, 393-454). La cita, en 425.

16. Los publicó en 1922 el padre Zarco Cuevas. Los ha vuelto a publicar, precedidos de valioso estudio, Daisy Rípodas Ardanaz (Valladolid, Inst. de Coop. Interamericana, Universidad de Valladolid, 1922), ed. de la que tomo la información. Quiroga fue canónigo de la catedral del Cuzco en 1568, Visitador General en Arequipa por orden del virrey Toledo en 1570 y se encontraba en Charcas en 1573. 
ma, de donde toma la acepción de "enfermero de hospital", alude a un español caritativo. Más rica es la información del $\mathrm{DH}$, que registra a la palabra como americanismo, equivalente a "enfermero de hospital" y agrega: "De Barchilón, apellido de un español caritativo que vivió en el Perú en el siglo XVI"17.

BOCHINCHE. Granada ofrece una minuciosa explicación: "Desorden, escándalo, barullo: confusión y alteración del concierto propio de una cosa" y se detiene en las causas: "por efecto de la ineptitud o abandono, travesura o malicia de la persona o personas que dirigen su ejecución”. Más localista es la información de Ciro Bayo en su Vocabulario criollo español sudamericano (Madrid, 1910) pues, luego de aludir a 'bulla' y 'alboroto' nos dice: "Derívase, sin duda, de la confusión y zaragata que se arma en pulpería y boliche donde se juega a las bochas". Pagés se remite a Palma y ha de coincidir con el DH en cuanto a 'alboroto' y 'asonada'. Calcaño (op. cit., § 694) rechaza lo de 'asonada' que defiende la Academia y piensa casi como Granada, sólo que califica la alteración del orden como "regularmente ocasional". Boyd-Bowmann recuerda que en México puede significar 'fiesta desordenada' y 'algazara'.

BOTAR. En Nebrija: "echar fuera, extrudo". Los lexicógrafos extranjeros repiten a Nebrija:

Palet, 1604, "chasser dehors"; Vittori, 1609, "botar, echar fuera". Covarrubias, 1611, agrega esta novedad: "Botar afuera, echar alguna cosa que está dentro de otra cosa con alguna

17. Daisy Rípodas Ardanaz ha dedicado al tema los siguientes artículos: "Barchilón, enfermero de indios: del Hospital de Huamanga al Diccionario de la Lengua" (Estudios sobre política indigenista española en América, tomo 3, Seminario de Historia de América de la Universidad, 1977 , pp. 367-374); "Barchilón, hombre y vocablo. Historia de un americanismo" (BAAL, 52, n? 203-204, 1987, pp. 161-179) 
violencia", (énfasis mío) y es vocablo francés bouter; esas ideas las mantiene y repite Echegaray, que arriesga etimologías. Sejournant ha ofrecido una larga explicación, aparte de aludir a algunos términos marinos: "Chasser, faire sortir, arracher, tirer, pousser dehors" con sus equivalentes lat. expellere y extruder $^{18}$. Pagés la da como proveniente del bajo lat. boutare $\mathrm{y}$ del lat. pulsare 'arrojar o echar con violencia', y se autoriza con el siguiente texto de Nebrija: "dos dientes que le habian botado de la boca". El DH trae 'arrojar, echar, lanzar' y cita ejemplos del Libro de Alexandre y la Gran Conquista de Ultramar, 1503; Pulgar, Crón. de los Reyes Católicos; Las Casas, Apolog. Hist., y recoge algunos ejemplos de Cuervo en sus Apunt. En Canarias se oye botar y botarate (Alvar, RFE, Anejo LXIX; RDTP, XXI, 255), que expresa la primera extensión semántica en América. Vid. Fontecha, Glosario.

BROMA. Echegaray recoge cinco acepciones para la palabra a) 'cascajo, ripio'; b) cierto guisado que se hace de avena quebrantada como el farro y sémola de la cebada y del trigo y conjetura antecedentes en el gr. brómos y el lat. bromos; c) uso metafórico: 'bulla, algazara, chanza burla'; d) 'especie de caracol de figura cilíndrica y serpenteada, el cual penetra y horada la madera; e) prefijo técnico, 'alimento'. Sejournant registra solamente tres: a) "ver qui carie les bois, lat. teredro; b) "chose pesante qui pese beaucoup \& qui est de peu valeur; se dit également d'une personne pesante, ennuyeuse, lat. gravis, ponderosus; c) "décombre des batiments, lat. rudera. Sejournant incorpora además bromado "Pesant-lourd, fatigant, incommode, lat. molestus, importunus". Pagés conjetura pro-

18. El REW (1228 c) nos remite al fr. bouter, prov. botar, de donde el it. buttare, esp. ptg. botar. Para Devoto (Diccionario s.v. 'gettare', c.f. las precisiones sobre matices parecidos a los de el español). Bloch-Von Wartburg (Dict. Etym. s.v. bouter) lo da como antecedente del español, con los antiguos valores (s. xiii) de 'frapper, pouser, germer, mettre'. Consúltese el valioso estudio de Harri Meier, "Frank bötan 'stossen' in romanischen" (RLRo, XXIII, 1959, 270-286) 
cedencia del ing. worm "el molusco que se introduce en la madera de los barcos" y cita a Fdez. de Oviedo. Otros lexicógrafos invocan al gr. bromos y el mismo Pagés anota lo del "quisado" tomado textualmente de Echegaray e incorpora otra entrada de broma, sin etimología, para explicar; "cascajo o ripio que se echa en los cimientos de los edificios para trabar las piedras grandes". En el DH hallamos: "fig. palma, postema o cosa pesada", alegando autoridades en textos de Quevedo y de Tirso; se consigna además bromar 'abrumar, molestar', ambas palabras atestiguadas en las Representaciones de Horozco. Por lo visto, hay mucho por investigar. Del Rosal, 1601 , recuerda que "en griego es la roedura del ratón o polilla, o lo que así mordido o comido; y porque los libros viejos acontece, de muy arrinconados y olvidados, estar así, los llamamos bromas". Años después, en 1620, leemos en Sobrino: "si chiama ogni cosa peso, e di poco prezzo, peso noioso, tarlo o vermeche rode schiuma o bava che si fa stando in collere".

CACHACO. El DH solamente registra las acepciones de 'lechuguino', 'petulante' con vigencia en Colombia y orienta su información sujetándose a cuanto al respecto dice Cuervo en sus Apuntaciones. Tal como dice Martha Hildebrant, no tenemos todavía explicación para los significados, tan distintos y contradictorios de cachaco en el Perú y Colombia. Efectivamente, el último diccionario de colombianismos (HaenschWerner, Inst. Caro y Cuervo, 1993, s.v.) destaca: "Persona bien educada, de buenos modales" con la aclaración de que "puede tener, según el contexto, una connotación despectiva, en el sentido de lechuguino, petimetre. La investigación está abierta.

CACHARPAS. En el Vocabulario rioplatense de Granada, 1889, leemos: "Conjunto de objetos o prendas de uso, en especial cuando son viejas. Así las piezas que componen un recado de montar y los trastos de una familia pobre, cuando ya tiene algo de uso, se llaman cacharpas, y también se da este nombre a las insignias y condecoraciones de un general". El DH la da, como $\mathrm{MH}$, procedente del quichua cacharpayani 
'despachar', 'avisar al caminante' y se remite a la autoridad de Granada. Actualmente en Costa Rica nombra a los "zapatones grandes y viejos, poco usados" y fundamentalmente designa "el vehículo viejo y que funciona mal", significado corriente hoy en el Ecuador para la palabra en singular; así Carlos Joaquín Córdova (El habla del Ecuador, vol. I, s.v.): "Un sombrero viejo es una cacharpa: un automóvil desvencijado y ruidoso es también una cacharpa"

CACHIMBA. He aquí una papeleta dicutida y discutible. Algunos léxicos consignan, como $\mathrm{MH}$ acá, el femenino; otros desarrollan la palabra en masculino, y hay quienes dedican una papeleta a cada palabra tratándolas como distintas. En el Perú la forma corriente es cachimba, y en torno de ella desarrollaremos nuestra exposición, aunque no hay claridad en el comportamiento de las voces. Cachimba es, para Granada, la "pipa de fumar ordinaria y tosca, en especial la que usan los negros viejos"; y él mismo recuerda la explicación de Palma para cachimbo, circunstancia que le sirve para arrancar esta explicación:

"Acaso sea el Río de la Plata donde con más propiedad se aplique la voz cachimba, que es la antigua casimba, como actualmente en Cuba y en el Perú, donde la palabra conserva su forma portuguesa, lengua de la cual parece haber pasado a la española en América. Como quiera que sea, es necesario determinar la diversidad de sentidos que se da en América al cachimbo y a la cachimba. En port. cachimbo, pipa de fumar" (Vocab. rioplatense, 126)

Para cachimba Granada reserva otro apartado, donde nos informa; "voz importada del África, en donde significa la densa neblina que al caer la tarde se forma en algunos puntos de sus costas y también pozo artificial de sacar agua" (ibid. 125). Pero lo cierto es que cachimba era voz que ya circulaba en 1750 en Costa Rica con el valor de 'pipa de 
fumar', fecha muy anterior a la registrada por Corominas ${ }^{19}$.

Pagés registraba cachimba como americanismo y con el valor de "pipa, utensilio de uso común para fumar tabaco de hoja" y asigna al Perú el significado de "cívico o guardia nacional". El DH, con la autoridad de Lenz, la tiene por africana y la ubica en Chile; anota cacimba en Argentina, con el significado de "hoyo que se hace en la playa"; registra cacimbo como uso americano y le adjudica el valor de "pipa para fumar' difundido por Argentina (Granada) y Venezuela (Calcaño). Como de origen portugués la consideran L. y A. Millares (Léxico de Gran Canarias, Las Palmas, 1924). Corominas pensó en "la existencia de dos focos de difusión, uno brasileño y otro cubano", que resultan ser "los dos centros esclavistas más grandes de América" (Laguarda, BCP, 17, 1973, 132-35). Alvarado (Glosario de voces indígenas de Venezuela) registra cachimba como voz de pesca, "hoyo o cavidad hecha en la orilla del mar o de los ríos para proporcionarse agua potable". Y Calcaño apuesta por la palabra de género masculino: "tampoco alcanzo por qué ha de ser femenina".

Ya Malaret había conjeturado para cachimba origen africano, al notar su presencia en el portugués criollo de las islas del golfo de Guinea, de donde partían cargamentos de esclavos negros para el Nuevo Mundo. Y esa conjetura repite las que sobre tal origen africano habían adelantado en su momento Pichardo, Granada y Arona: en el fondo todas esas ideas deben ciertamente vincularse con la afirmación que Lizardo Alvarado atribuye a Kar F. Von Martius de que la palabra "pertenece verosímilmente a una lengua de los negros" ${ }^{20}$. Ya Alvarado interpretaba ingenuamente que la forma

19. Miguel Angel Quesada Pacheco, Diccionario histórico del español de Costa Rica, Costa Rica, Univ. Estatal a distancia, 1995. s.v. Hoy el Dic. de Argentinismos de Augsburg da: cachimba 'pozo natural o artificial de agua potable'; cachimbo 'pipa para fumar'. Y no registra cacimba. 
del femenino cachimba se debía a influencia del femenino pipa: al ser cachimba sinónimo de esta palabra, era también natural, para Alvarado, que cambiase el género original masculino de cachimbo por el femenino respectivo. Con más precisión podríamos hoy hablar de las investigaciones de J. Raimundo, para quien el étimo de cachimbo se ofrece "en la voz bantú de Mozambique" graficada njimbu o chi-imbo 'concha', 'vasija', 'recipiente hecho de la nuez del coco', cuyo diminutivo es ja-njimbu o ka-chi-imbo ${ }^{21}$. Los trabajos de Raimundo tienen presente que los árabes de Sofala fueron quienes propiciaron el uso del tabaco entre los negros de la zona. $\mathrm{Al}$ mismo tiempo, R. Mendoça piensa en un término de la lengua kimbundu kixima 'pozo', 'cosa hueca' "con cambio del prefijo kipor el diminutivo $k a$, fuente también del doblete cacimbo 'hoyo que se hace en la tierra para sacar agua potable, balde, cubo'. A Nazario estas apreciaciones le parecen "más juiciosas"; seguidamente, tras apreciar que el desarrollo de /b/ después de $/ \mathrm{m} /$ tiene en bantú explicación natural, Nazario afirma:

Es muy posible que fuera esta voz de Mozambique, con su terminación de masculino, vista desde el ángulo del portugués y del español, la que se empleara con más antiguedad en América para dar nombre al indicado artefacto de fumar. Así parece demostrarlo el uso que ha prevalecido en el Brasil $[\ldots]^{\prime 22}$

Nazario piensa que el desarrollo más tardío de la termi-

20. Beiträge zur Ethnographik und Sprachkunde Amerika's zumal bresiliens, Leipzig, 2 vols, 1867. (Apud Alvarado, Glosario de voces indigenas de Venezuela, II, 424)

21. Jacques Raimundo, $O$ elemento afro-negro na lingua portuguesa, Río, 1933; Renato Mendoça, A influencia africana no portugues do Brasil, Sao Paulo, 1933.

22. Manuel Alvarez Nazario, El elemento afronegroide en el español de Puerto Rico, San Juan de Pto. Rico, 1961, No 161) 
nación de femenino (seguramente consagrado ya en las décadas primeras del XIX) se debió a "causas a la vez independientes y simultáneas". Del Castillo Mathieu recuerda que en la costa atlántica "este vocablo alude al olor desagradable que deja el tabaco después de que ha sido fumado" y advierte asimismo que en la costa caribe no es usual llamar cachimba a 'la pipa'23.

CALATO. Pagés se refiere concretamente al Perú y anota: "desnudo, en cueros", pero agrega un texto de Arona.

CAMAL. Estamos ante una palabra cuya historia no nos es realmente conocida. Si es verdad que hasta ahora lo aceptado es que procede del lat. camus 'cabestro', ignoramos los caminos por los que ha terminado en algunos países andinos significando "matadero". Cierto es que entre las voces medievales del Glosario de Toledo leemos: "camus: cabestro". Pero aun cuando se halla favorecida esta procedencia, Von Wartburg ha propuesto la del céltico camba, y acá es donde las cosas comienzan a oscurecerse. Meyer Lubke (REW, 1565) está por el antecedente camus, y éste del griego. En el XVII, Covarrubias (cuyas etimologías son, a veces, de temer) propone una lectura sobre la que conviene, tal vez, reflexionar; según él, la palabra deriva del hebreo gamal, camellus: "Mudando la G media en $\mathrm{C}$ tenue: maroma o guindaleta delgada, que es lo mesmo que cabestro". Esto explica el camellus de su texto. El Dic. Etim. de Echegaray nos ofrece dos acepciones: a) 'cabestro' (de camu 'freno'), cat. ant. camal; b) anticuado, 'cadena gruesa, con su argolla, que se echa a los esclavos para que no se huyan'. Sugiere como etim. el gr. kamelos 'cuerda, cordel'.

23. El español de América hacia el siglo XXI, Bogotá, Inst. Caro y Cuervo, 1992, vol. 2. Más adelante, Del Castillo Mathieu admite que esta voz está asociada con los negros esclavos; para su etimología quimbundo, vid. cachumbo. Para información más esclarecida véase su libro, Esclavos negros en Cartagena y sus aportes léxicos, Bogotá, Inst. Caro y Cuervo, 1982 . 
Como los léxicos registran dos acepciones, 'cabestro' y 'ramal', se han dejado oir varias opiniones. García de Diego tiene objeciones; en tanto que la palabra significa "ronzal o cabezón", es decir cabestro, deriva del lat. camus y carece de razón Von Wartburg para remontarse al céltico camba; pero en cuanto significa "palo, rama", evidentemente deriva del céltico camba. Naturalmente VGD discrepa asimismo de algunas etimologías conexas propuestas por Corominas; por eso leemos en su Contribución al Diccion. Etimológico, s.v. ramal: "cada uno de los cabos de que se compone una soga", y seguidamente en ramus: "tallo de un árbol". De toda esta oscura discusión, una cosa es cierta: el parentesco de cabestro con soga; pero eso no esclarece la relación cabestro-matadero (¿entre los carniceros?, ¿entre matarifes?, ¿entre los usuarios de las carnes beneficiadas?, ¿entre los vecinos del camal?). Faltan datos que esclarezcan el camino seguido, pues hasta ahora se diría que cabestro y matadero no parecen ser sino los dos extremos del circuito.

CAMOTE. Convive en los léxicos como batata y patata; un buen testimonio nos lo ofrece el padre Las Casas (Hist. Ind., II, 274) cuando recuerda: "Su bastimento eran pan de maíz y algunas raíces comestibles, que debían ser las que en esta Española llamamos ajes u patata y en la Nueva España camotes" ${ }^{24}$. Domínguez la tiene, entre otras voces americanas, como una "especie de batata grande que se cría en Nueva España y otros países de Indias". Pagés la incorpora como mexicana con el valor de 'batata'. Para el DH es un americanismo procedente del mex. camotlí, con idéntico significado. Ya el padre Acosta, en 1598 hablaba de ella como de "otro nombre americano de la batata" Oudin, 1607, la registra remitiendo a batata. Batata es la voz consignada por Vittori, 1609, con esta explicación: "Sorte de racines comme gros chervis et sont bonnes à manger". Una alusión americana se

24. En Apologética, 1, 60, el mismo Las Casas nos dará otro nombre: "yucaba, la media sílaba luenga". 
lee solamente en Minshev, 1617: "A root good to eat growing India, the Potatoe route". En el Dictionary of the French and English de Ronald Cotgrave, 1611, leemos: "Racine provenante des Indes, qui est bonne à manger rotie". Describiendo el Arzobispado de México, Váquez de Espinoza explica:

"Muchas diferencias de raises, como son patatas, que en aquel reyno llaman camotes, son grandes, de muchos colores, blancas, moradas, amarillas, azules y de otras suertes, tienen el mismo sabor que las que se crían en Málaga" (Compendio y descripción de las Indias $\$ 485)$.

Sejournant resulta todavía más explícito, pues nos dice: Batata, "Batate ou Patate, racine de l'Amérique dont on fait des confitures; elle sert aussi d'aliment aux négres". En francés ocurre que las dos voces españolas han terminado por confundirse en sinonimia, y por eso "para evitar confusiones, a la batata se le llama también patate douce. Patate se ha diferenciado muy tarde (s. xviii) en el sentido de patata, 'papa', bajo la influencia del ing. potatoe; pero esta innovación no ha prosperado, y, aunque se siga empleando con fortuna diversa, ha sido sustituida generalmente por pomme de terre" (Alejandro Cioranescu, Los hispanismos en el francés clásico, Madrid, $R A E, 1987$, s.v.). Marius Sala recoge 'mentira, bola' para $\mathrm{Ch}^{\text {' e }}$ y Perú, 'desvergonzado y bribón' para México y las expres nes mexicanas tragar camote "expresarse con dificultad $\mathrm{p}$ no saber o no querer hacerlo claramente" poner a uno col: i ) camote "regañarle duramente o darle una paliza" (I, 34-35. .

CAPAZ. El DH, en su séptima acepción, la acoge como americanismo: en realidad acepta la observación formulada por Cuervo (Apunt.: "el uso de capaz por 'posible', probable, fácil, se conoce en Méjico, y sin duda procede de España”).

CAPORAL. Leemos en Sejournant: "Il se dit d'un chef aux travaux qui commande une position de travailleurs. Operam inspector". Pagés explica: "el que es o hace cabeza de gente, 
y como tal la manda"; respalda su explicación con un texto de la Recopilación de Indias y añade seguidamente: "El que en las haciendas de campo tiene bajo su cargo y responsabilidad los ganados que se emplean en la labranza, y también el que tiene a su cargo una estancia de ganado". El DH repite el texto, pero aclara la fuente: Recopilación, Lib 2, título 10, ley 30, y cita la Vida de San Ignacio de Loyola de Rivadeneyra.

CARÁTULA. Aun cuando está bien extendido en América (Colombia, Ecuador, México, Perú) el uso de carátula con el valor de "portada de un libro o cuaderno", no sabemos realmente cuándo adquirió esa significación, aunque sí tenemos a la mano elementos que nos permiten afirmar que no es de data reciente. Aparece consignada en el Diccionario de mejicanismos de Félix Ramos de 1896, aunque solamente la reconoce como vigente en el Distrito Federal. Años después, 1899, García Icazbalceta la incorpora a su Vocabulario de mexicanismos. Para Calcaño, en Venezuela, era una voz aceptable y rechazaba el calificarla de barbarismo; según él con carátula se aludía a "la cubierta de papel que se pone a los libros encuadernados a la rústica, y que consta de dos hojas planas, la portada, o anteportada y la final, que cierra" (op. cit. § 718). Moreno de Alba fija para México una fecha antigua, 1805, en el primer tomo del Diario de México, y piensa que el hecho de que aparezca varias veces en el citado volumen permite "suponer que por entonces era ya voz común, sin duda con bastante antiguedad"25. Admite también otros matices, y así el último Diccionario de argentinismos editado por la Universidad de Augsburg consigna tres nuevos valores: "primera plana de un cuaderno escolar" donde constan datos personales del poseedor; "primera página de un libro impreso" donde se registra el título, el nombre de autor e impresor; y, por último, "en un expediente, hoja que lleva el número, la fecha de ingreso y el título identificatorio".

25. José G. Moreno de Alba, Minucias del lenguqje, México, FCE, 1992, p. 57. 
CARPA. Pagés, como tercera acepción, y sin calificar de americanismo da como su equivalente 'tienda de campaña' y se autoriza con un texto de Antonio de Solís. El DH se acoge, en verdad, a la opinión de Arona, deriva del quechua carppa, la registra como americanismo y le da como equivalente: "toldo, tenderete de feria, tienda de campaña", y la autoriza con Palma para el Perú y Román para Chile. Así lo repite para Colombia, años después (1983), Alario en su Lexicón de colombianismos. Con algunas leves aclaraciones la recoge Córdova hoy para el Ecuador: "tienda de campaña de lona u otros materiales resistentes e impermeables". Conviene, tal vez, puntualizar que debe correrse la fecha de 1890 defendida por Corominas hacia el siglo XVII. Aun cuando Córdova defiende el año de 1700, fecha de la 3a. edición del Arte y Vocabulario Quechua del jesuita Diego de Torres Rubio, donde consta la palabra carpa, debe tenerse en cuenta que esa edición tiene agregados del jesuita Juan de Figueiredo sobre la lengua Chinchaysuyo y no agrega nada a la edición de la sección española; por lo tanto las fechas de carpa deberían correrse a las ediciones de 1603 (que no he podido ver) o de 1619 .

Todo contrasta ciertamente con lo que hoy defiende el Diccionario de argentinismos de la Univ. de Strasbourg; de las cuatro acepciones que registra, las dos que de algún modo nos interesan serían: "Estructura desarmable formada por tubos o palos, estacas y cuerdas, sobre la que se tiende una tela, lona o plástico, y que sirve de alojamiento al aire libre", válida también hoy para nosotros: y la segunda acepción alude a lo mismo "pero de menor tamaño, que se alquila en las playas para protegerse del sol"; es decir, lo que nosotros llamamos sombrilla.

CHAPETÓN. Granada anota en su Vocabulario de 1889: "Inexperto, bisoño. Dícese del que no se da mañas para ejecutar bien una cosa" para una primera acepción y explica una segunda diciendo que así se decía "de la persona poco experimentada en las cosas del país". Recuerda que se usaba 
como sustantivo o adjetivo. En ambos casos, la explicación está orientada al campo semántico de la 'experiencia'; lo confirmamos al leer su explicación de chapetonada: "Acción u obra mal ejecutada, por falta de conocimiento de los usos del país, o de la suficiente práctica, habilidad y desenvoltura, en contraposición a la baquía de los habitantes nativos", y lo reconfirmamos al leer esta explicación para pagar la chapetonada: "resultarle a uno algún daño o pérdida de lo que ha ejecutado sin el suficiente conocimiento de las espinas que traía consigo el negocio que emprendiera o por haberse metido en honduras". Según Peñalver, la palabra alude solamente al 'europeo'. Domínguez es un tanto más explícito: "En el Perú, europeo que pasa a aquel reino o se establece en él". Seguidamente, s.v. chapetonada arriesga esta explicación: "La primera enfermedad que padecen los europeos después de haber llegado al reino del Perú, ocasionada por la mudanza del clima", con lo que parecería aludir al clima serrano. Pagés aventura que la palabra se deriva de chapuz y dice escuetamente: "En algunos países de América, se dice del europeo recién llegado", y luego s.v. chapetonada repite textualmente a Domínguez. Que el significado de 'novicio', 'bisoño' parece haber tenido prioridad en el siglo XVI parecería confirmarlo el hecho de que es la significación preferida por los lexicógrafos extranjeros: Palet registra nouveau, Oudin apenas agrega: nouveau à quelque chose, Minshev luce un escueto novitius. Pero podemos leer, con extrañeza en Sejournant: "Nom qui donnent les mexicains aux Européens \& aux espagnols qui arrivent chez eux"; y luego, su versión latina: Ex Europa in regiones Mexicanas advens pauperculus. En los tres primeros, ni una alusión a América.

Bisoños era una socorrida manera de entender chapetón o gachupines ${ }^{26}$. Tres textos diferentes nos pueden ilustrar tales valores (y un rico abanico semántico, el de Vargas

26. "Gachupin y chapetón se usaban en los siglos xvi y xvil en el mismo sentido de novato en tierra americana. La primera forma se prefería en 
a) BERNARDO DE VARGAS MACHUCA, Milicia y descripción de las Indias, 1599, Lib. II: "Necesaria es la gente baquiana. Soldados chapetones corren riesgo. Si fuere jornada para algún socorro, castigo o pacificación o reedificación, nombrará su caudillo, el cual nombrará su alférez y sargento y hará la gente necesaria con cuidado $\mathrm{y}$, si fuere posible, sea toda gente diestra y baquiana, porque será de gran inconveniente llevar gente chapetona, así para el mismo soldado, como para el caudillo, porque como no están hechos a la constelación de la tierra, ni a los mantenimientos de ella, enferman y mueren [...]" (Cito por ed. Madrid, 1892, tomo I, 115).

b) INCA GARCILASO DE LA VEGA, Comentarios Reales, II Parte, Lib. II, cap. 36, 1617: "Lo que Gómara dize que se marearon los piçarristas, es de saber que assi los visoños que nuevamente van de España (que en la lengua de los barloventanos se llaman chapetones) como los pláticos de la tierra, que llaman baquianos si están mucho tiempo en los llanos que es la costa de la mar, cundo buelven a la sierra marean [...]" (Cito por ed. Rosenblat, I, 221).

c) ANTONIO VÁSQUEZ DE ESPINOSA, Compendio y descripción de las Indias Occidentales, ms. 1630-1639):

(1) En México, describiendo el hospital de san Hipólito, del que envían a Veracruz cargamento de viscocho regalos y dulces, que van dexando en puestos para

la Nueva España, la segunda en el virreinato del Perú" (José Durand, "Baqueanos y chapetones, criollos y guachupines" (Cuad. Amer. 15, 1956, 148-162; la cita en p. 151). En la Declaración de los hombres propios de la Milicia de Vargas Machuca se lee: "Chapetón: es hombre nuevo en la tierra". Por cierto, Lope (La dama boba) usa la palabra con el valor de "español que regresa de las Indias" (Fontecha: 'inocente', "pobre hombre'). No conozco la monografia de P. Montesino citada por Carrión. 
curar, y regalar los pobres enfermos, y todos los que hallan en el puerto, en especial Cachupiñes, que llaman $€ n$ aquel Reyno a los recien llegados, y en el Piru, y tierra firme Chapetones".

(2) En Nicaragua "tienen tambos, mesones o ventas; que sirven de refugio a los españoles pobres, que llaman chapetones a los recién llegados".

(3) Hablando de Chile, en el valle de Atacama: "Este valle se llama Hatunllulla, que quiere dezir gran mentiroso, porque suele hazer muchas burlas a los Chapetones, o visoños, que pasan por allí, por no saber la tierra, sino es que llevan algún indio de guía, y otra persona que sepa lo que pasa" (Cito por ed. Ch. Upson C'ark, Washington, Smithsonian Institute, 1948, parágrafos 456, 726 y 1757 respectivamente).

Hoy las cosas van cambiando. Los diccionarios de argentinismos y colombianismos preparados por la Universidad de Augsburg registran hoy, como primera acepción: "Persona natural de España", en tanto que el Diccionario de Uruguayismos preparado por Ursula Kuhl de Mones para la misma colección registra: "Persona que es torpe o inexperta y revela poca habilidad para desenvolverse en un trabajo"; lo que es, de alguna manera, un retorno a las fuentes.

CHARQUE. En su Vocabulario rioplatense, escrito entre. 1845-48, Francisco Javier Muñiz registra charque con esta aclaración: "Carne seca al Sol y al aire. Se diferencia de la cecina o tasajo en que esta preparación consiste en lenguas o tiras de carne angosta más o menos arredondeadas y en láminas o bandas anchas y largas cuanto permite la tajada de pulpa que se diseca y adelgaza cuanto es posible" (BAAL, V, 422-23). Granada lo presenta exclusivamente como "tasajo. Carne seca, sin sal, cortada en lonjas delgadas" y no cree que su uso sea muy extendido. Marius Sala registra s.v. charqui 
"tajada de frutas o legumbres secada al Sol en Bolivia y también persona flaca" y las expresiones darle vuelta al charqui "reiterar lo que se está ejecutando", estar con el charqui largo "tener el labio inferior caído en gesto de desagrado", ambas chilenas. Aduce asimismo charqueda "acto de hacer charque, de reducir a estado de charque o destruir la reputación ajena", en el Río de la Plata.

CHICHA. Alvar cita este pasaje de Gutiérrez de Santa Clara, Quinquenarios, VI, 241:

"También beben todos de otro género de vino que llaman chicha, que se hace de maíz mascado por la boca. Asimismo se hace de una planta [...] que llaman quinúa [...] y todo brebaje que se hace en esta tierra llaman chicha o azúa".

Para Granada, se trata de una "bebida que prepara la gente campesina de las provincias argentinas arribeñas, haciendo fermentar el maíz, a imitación de los indios del antiguo Perú, que fueron sus inventores". Alvarado la reconoce como taína y la presenta como "bebida refrescante, ligeramente fermentada y de consistencia espesa", usada en Venezuela "durante los días de Navidad". Calcaño, con su habitual fantasía, sostiene que "el origen del nombre está en que los indígenas llamaban chichi al sol, y le ofrendaban su bebida favorita, que suponían era también la del dios". Algunos lexicógrafos la reconocen oriunda del Perú, otros parecen tener distinta información; así Sejournant nos ofrece esta curiosa descripción: "Boisson faite de mays ou de blé d'Inde, ou de Turquie, en usage dans les Indes Occidentales", pero su versión latina es menos explícita: Potio examericana frumentu confecta y alude sólo al maíz. Pagés la vincula con el lat. zythum "especie de cerveza" y nos la refiere como "bebida alcohólica que resulta de la fermentación del maíz en agua azucarada, y que se usa en América”. Y más adelante, tratando de explicar la expresión calma chicha, defiende la procedencia del lat. sessa 'sentada'. Pero hay que tener presente 
que la voz aparece en textos del XVI y el XVII con el valor de 'cosa de poca importancia' (MH recuerda algún uso de Lope, invocado por Morínigo y Fontecha la registra en Autos y Farsas del XVI de R. Jammes y M. T. Maurin, así como consigna las expresiones De chicha y nabo 'despreciable', en textos de Quevedo y No tener chicha 'tener pocas carnes o pocas fuerzas', en texto de Pérez de Ayala). Estamos probablemente ante dos acepciones distintas. García de Diego (Contrib. al Diccionario Etimológico, 332) (a propósito del cast. chicha) remite a insicia; tiene a chicha por voz infantil para designar 'la carne' y como voz corriente en frases como "hombre de pocas chichas", por 'débil' y 'poco musculoso'.

CHICOTE. Granada la tiene por "latiguillo del jinete", látigo corto y es consciente de que en Chile representa "un azote de cuero, de cordel, de cerda". Calcaño casi coincide con la explicación, pero la tiene por palabra castellana; al explicar chicotear 'pelear', recuerda que "el habla antigua tuvo el verbo chicotear, 'disputar' " (op. cit. \# 219). Sejournant traduce así: "Terme de mairinier, est le bout d'un cordage". Pagés la presenta como mexicanismo: "látigo, azote largo, delgado y flexible, de cuerda, ballena u otra materia, con la que se aviva y castiga a las caballerías". Delfín Garasa, con datos sobre otras voces americanas, afirma que en nuestra "montaña peruana denomínase chicotillo a un áspid que ataca o se defiende a zurriagazos con su propio cuerpo", pero no indica fuente (Fil. IV, 188-90).

CHÚCARO. Según Granada, se trata del "animal arisco, que a la presencia del hombre se asusta y embravece, y acomete o bien se dispara". Y en seguida, repitiendo a Salvá, lo ubica en el Perú. Pagés lo atribuye directamente al Perú: "arisco, bravío" y da los socorridos ejemplos: "caballo chúcaro y yegua chúcara", tomados del DRAE 1899. Friderici sugiere revisar cimarrón. Actualmente en el Ecuador se agrega esta significación otra, familiar: "Novato, el muchacho que ingresa al primer curso del colegio secundario y a quien le gastan los primeros días de asistencia las bromas más pesadas". Para 
García de Diego, proviene del quechua chucru. Marius Sala registra para Colombia estar chúcara una cosa por "ser difícil de comprender o ejecutar; ser delicado o conprometido un asunto"

CHUECO. Palabra largamente ausente de los diccionarios españoles. Granada la da como equivalente de "Estevado, patituerto. Dícese asimismo por trasl., del calzado que tiene los tacones torcidos de tanto usarlo. También por trasl., dícese de la persona que está extenuada o decaída y anda como trastavillando: Está chueco, anda chueco". "En Ecuador (dice Malaret en $B A A L, \mathrm{X}, 597-98$ ) el chueco no es el patojo, patituerto o patizambo, ya que no tiene piernas ni pies torcidos; es el que pisa mal por no haber tenido buena educación física. En el Perú no es patuleco; chueco dícese del individuo que tiene las puntas de los pies dirigidas hacia adentro y patuleco el que las tiene hacia afuera". Hoy, para el Ecuador, Carlos Córdova registra (El habla del Ecuador, I, s.v.) "Imperfecto, manco, defectuoso". García de Diego lo remite al lat. soccus.

CHUSCO. Para Peñalver es el "que tiene gracia y donaire". Domínguez lo registra como "gracioso, donairoso, salado"

CIMARRÓN. Como un hispanismo de América lo considera Martha Hildebrant, con larga trayectoria americana y muy característico del español de América. Los lexicógrafos extranjeros recogen testimonio de su conflicto semántico. Así, Sejournant nos dice: "Sauvage, farouche, indompte. Il se dit communement des taureaux \& d'autres animaux \& quelquefois des gens rustiques" y lo confirma con su equivalente latino: indomitus. En Littré podemos luego leer (s.v. marron) una alusión exclusiva a las personas y al origen hispánico: "Se dit du negre qui s'est enfui dans le bois pour y vivre en liberté. Negre marron, negresse marrone. D'après Scheler, le mot marron se disait anciennement simarron, qui vient de l'Espagnol cimarrón, 'sauvage' ". Pagés registra las dos acepciones como de origen americano: a) "el esclavo doméstico que 
huye del campo y se hace montaraz" y b) "aplícase a la planta silvestre de cuyo nombre o especie hay otra cultivada". Registra además yaya cimarrona como "cierto árbol que tiene tronco muy ramoso, hojas oblongas y brillantes, flores amarillas, pequeñas, solitarias, en la axila de sus hojas, y el fruto sirve de alimento al ganado de cerda". Es probable que un detenido estudio en los grandes centros americanos nos permita reconstruir cómo se ha ido desarrollando la historia de la palabra; así, sabemos que en 1571 en Costa Rica aludía al "esclavo negro que huye y se refugia en el monte"; que a fines del XVII se aplicaba al ganado montaraz; y un interesante ejemplo de 1714 nos ilustra su oposición a 'gente conocida': “y no avia cimarrones sino ganado que todos son conocidos de sus dueños". Ya en el siglo XIX terminó aplicándose a objetos y luego a personas (Quesada Pacheco, s.v.). Nazario nos informa cómo en Puerto Rico "la voz cimarrón, adj., se dijo antiguamente del negro que huía de la esclavitud y se refugiaba en los montes"; la tiene por de probable origen antillano y nos explica que en los primeros tiempos de la colonización en América se aplicó "a los indios alzados y, por extensión, a los animales que se hacían montaraces". La palabra emigró con facilidad; fue muy usada en las colonias francesas de América, de donde pasó a Francia, con el valor de "clandestino" hacia 1832; ya en Francia desde mediados del XVI, maron aparece con el sentido de 'esclavo evadido', con evidente pérdida de la sílaba inicial ${ }^{27}$. En inglés, ya aparece usada en la obra Sir Francis Drake Revived, 1628, bajo la forma symerons con la significación de "black people about eighty years past fled from the Spanish masters (in Jamaica)". "En dicha isla todavía se da el derivado maroon a los negros descendientes de aquellos esclavos establecidos en lo que se llama Maroon Territory"28. La significación más general era ciertamente la

27. En francés debió intervenir una confusión con marran 'execrando'; de tal confusión hay un ejemplo en 1570: "le marron Español". En 1694 tenemos otro ejemplo: "on apelle marrons les nègres fugitifs". En el XVIII comienza a aplicarse también a los animales (CIORANESCU, Los hisp. en el francés clásico) 
que, citada por Nazario, expresaba J-B Balat en sus Memoires des nouveaux voyages daits aux iles françoises de l'Amérique: marons es el nombre que reciben los 'negros fugitivos' que huyen de sus patrone para 'no trabajar' o para 'evitar el castigo corporal'.

Un testimonio de las acepciones confusas vigentes en el XVII nos lo puede ofrecer Vásquez de Espinosa, en cuyo Compendio y descubrimiento (citado en otros lugares) de 163019 podemos leer, describiendo la provincia de Carangas:

"El temple es frío, la tierra llana con algunos serros; por ella demas de ganado manso de Carneros de la tierra y de Castilla, ay grande cantidad de ganado silvestre y cimarrón, que son guanacos y vicuñas, viscachas" (\# 1644)

Anteriormente, en un pasaje relacionado con Puerto Rico, Vázquez de Espinosa explica que Juan Ponce de León, tras fundar y conquistar Puerto Rico, se quedó a vivir en la ciudad; a lo largo del relato menciona la ocasión en que tuvo que luchar "contra los negros cimarrones y contra los corsarios" (\# 114). Por un lado, cimarrón aplicado a animales y a seres humanos; por el otro, cimarrón opuesto a manso.

No es de extrañar. Ya a fines del XVI, 1589, el mexicano Joan Suárez de Peralta, en su Tratado del descubrimiento de las Indias, había dejado testimonio de que cimarrón podía significar "sin dueño conocido". Efectivamente, en el capítulo Inicial de su obra, hablando de las Indias recordaba ${ }^{29}$ :

28. M. Alvarez Nazario, El arcaismo [...], 221-222.

29. Suárez de Peralta terminó su ms. en 1589; lo descubrió Jiménez de la Espada en la Biblioteca Provincial de Toledo y lo publicó en 1878 Justo Zaragoza, de quien Granada toma, con algunos errores de transcripción, este primer fragmento. Según sus contemporáneos, Suárez "no tenía sino una poca de gramática, aunque mucha afición a leer historias". 
"la riqueza que han tenido y tienen de oro y plata y mucha suma de ganados [...] quel ganado vacuno y yeguas son tantas, que se crían en los campos y montes, bravos, que llama çimarrones, ques sin dueño, ni se puede conocer cuyo es, que no se aprovechan dél si no es del cuero y sebo, que la carne queda perdida en los campos donde la consumen los perros bravos, que son çimarrones que se crían en los montes, los cuales son tantos ya que hacen mucho daño en las gentes"

Capítulos más adelante, tenemos este otro testimonio:

"Toros no se encerraban menos de setenta y ochenta toros que los traían de los chichimecas, escogidos, bravísimos que lo son a causa de que debe haber toro que tiene veinte años y no ha visto hombre; que son de los cimarrones, pues costaban mucho estos toros y tenian cuidado de los volver a sus querencias, de donde los traían, si no eran muertos aquel día u otros" (Cap. xxv) ${ }^{30}$.

Granada no aludirá a los negros en su Vocabulario; la palabra, según él, se limita al "Animal montaraz o planta silvestre, en contraposición al doméstico o manso, y a la que se cultiva en las huertas". Y por supuesto menciona el mate: "Al mate amargo, para distinguirlo del dulce, se le llama cimarrón, como si dijéramos bravo, que lo es en efecto para los paladores no acostumbrados a gustar la infusión de la yerba en el estado de rusticidad en que la naturaleza la ofrece". Pero incorpora un fragmento de Alejandro Magariños Cervantes, que quiere recordar que mientras se llama cimarrón "a los negros esclavos que huyen a los montes, y a las plantas silvestres; pero en el Plata aplícase el adjetivo con característico significado al perro salvaje, oriundo de los que

30. Mis citas por la ed. de México, Secretaría de Educación Pública, 1949 , con notas de Gómez de Orozco; la primera cita, pag. 1; la segunda, p. 100 . 
trajeron los españoles".

Aparte de estos desacuerdos que miran a la significación, cimarrón hace frente todavía al relacionado con su etimología. Corominas propuso y defendió desde 1956 que el origen estaba en cima 'cumbre' + el sufijo -arrón, y se satisfizo con la explicación de que las alturas (=las cimas) eran el objetivo de la huida ya fuera de los individuos o de los animales. En 1973 R. Laguarda, disconforme con la propuesta, revisa con detenimiento las explicaciones de Arona, estudia las documentaciones recogidas por Friederici y revisa con algún empeño el texto de Fernández de Oviedo, de $1535^{31}$ del cual destaca el pasaje donde el autor narra que

\begin{abstract}
"topó con un indio cimarrón o bravo, que andaba en cuertos o con ciertas varas tostadas para pelar o matar, algunos puercos cimarrones o salvajes, de los quales hay innumerables en esta isla, de los que se han ido al monte de los que se truxeron de España" (énfasis mio)
\end{abstract}

Las conclusiones de Laguarda son interesantes a la vez que discutibles. Para él hay tres hechos dignos de tenerse en cuenta: a) a mediados del XVI, cimarrón era voz usada en América con los significados de 'salvaje' o 'bravo', en oposición a 'doméstico' o 'manso'; b) Como Oviedo no usa dicha palabra en el Sumario que publica en 1526, sino que ahí alude a puercos monteses para referirse a los que huyeron al monte, piensa Laguarda que el uso de cimarrón en 1535 era muy reciente; c) Oviedo no usa la palabra con el alcance de 'rebelde' pues en cada ocasión prefiere el calificativo de alzados, voz "que tiene ese significado desde los tiempos medievales y designa no sólo a los rebeldes sino a todos los que, huyendo de un peligro, se refugiaban en lugares elevados" (ibid., 302).

31. Rolando Laguarda, "Historia de un caso de simbiosis léxica. cimarrón y bagual" (Boletin de la Comisión Permanente, Madrid, 18, 299-307). 
Este último argumento es ciertamente débil, pues en el mismo texto que Laguarda ofrece como prueba podemos leer, tratando de los puercos cimarrones, que el autor alude a "los que se han ido al monte". Laguarda postula la fecha de 1599 para autorizar con otro texto americano la acepción de "raíces y frutas silvestres que llaman cimarrones": la Milicia y descripción de las Indias de Vargas Machuca; y ciertamente se despreocupa de que el Inca Garcilaso haya pensado en un origen americano para cimarrón $n^{32}$, pues lo único que parece alentarlo es que el Inca dijera que la palabra no era española, pues "muy pocas veces se equivocó en diagnosticar los vocablos que no eran españoles" (ibid., 306). En conclusión, Laguarda defiende que cimarrón es voz americana, probablemente arahuaca y "significaba todo lo que no estaba sometido al dominio del hombre, fuese vegetal o animal", y cree que las acepciones actuales de que ahora goza la voz "no constituían entonces más que una". Su apoyo más consistente: un pasaje de la Historia general y natural de las Indias, donde Fernández de Oviedo, hablando de la Española, dice:

"E assi muchos gatos de los domesticos que se truxeron de Castilla para las casas de morada, se han ydo al campo e son innumerables los que hay bravos y cimarrones que quiere decir en la lengua desta isla fugitivos" (Lib. XII, cap. ix Cita por ed. Madrid, 1851, tomo I, p. 400).

La discusión sigue abierta. Para el fr. marron, Dauzat nos ofrece esta explicación: "esclave nègre fugitive" (1667), recuerda el it. cimarone (1579) tomado de Benzoni y agrega: "forme apocopée de l'hispano-américain cimarrón" con esta curiosa acotación: "refugié dans un fourré, cimarra" (Dic. etym. s.v. marron). Y ya vimos que para Sejournant, la cosa se relacionaba con toros y gente rústica.

32. Vargas Machuca, en su Glosario s.v. cimarrón explica: "Es toda cosa huída y retirada". 
CODEAR. Tres datos interesantes. En el Diccionario español etimológico, manuscrito de 1720, de José de Siesso, nos enteramos de lo siguiente: "Seguir alguna persona y principalmente muger, halagándola para conseguir algo de ella: por ir junto a la cola de su saya" (énfasis mío); me parece indiciario de que tal vez si hurgásemos en la literatura costumbrista de fines del xviii/xix hallaremos los orígenes del uso limeño, que no parecería ser sino un matiz de la acepción registrada por Siesso. Sejournant nos ofrece esta nota interesante: "Terme peu en usage. Donner des coups de coudes, coudoyer, jouer du coude. Cubito compellere". Por último, Echegaray nos da lo siguiente: "Tratarse de igual a igual una persona con otra". Lo da proveniente del fr. couder.

CUJA. Pagés explica: "Armadura de la cama", e ilustra con un fragmento de Eugenio de Ochoa: "empleando la palabra cuja en la acepción de armadura de la cama". Según Ayala, 1693: "Derívase del lat. cosa, que significa la pierna, nalga o anca". No conozco el artículo de Baist ( $Z R P h, \mathrm{~V}, 1881$, 233-248) que entre otras palabras alude a cuja. En Costa Rica, en el siglo XVIII, era corriente como "cama rústica de madera".

DOLAMA. Pagés lo da procedente de dolames y éste de doler: "Ajes o enfermedades ocultas que suelen tener las caballerías". Es definición que ha trascendido a casi todos los textos. Dolames es lo que registra Sejournant con esta explicación minuciosa: "Défaut, maux, vices cachés que les bêtes de somme ou de monture ont quelquefois, \& qu'on leur fait passer aux termes de la vente". Max L. Wagner (Fil. III, 164168) da dolama como "achaque o enfermedad crónica de las personas" y la tiene por corriente en América; recuerda cómo se ha difundido en Brasil y Portugal el sufijo - ama, pero lo tipifica de raro en castellano: "Si en los ejemplos españoles citados por Corominas el sufijo -ama procede de la germanía, no veo por qué no sería así también en el caso de dolama, tanto más que, como comprobó el mismo Corominas, dolama ha sido a todas luces originariamente un término de chala- 
nes, es decir de gitanos. En el gitano español son varias las palabras con ese sufijo".

DONDE. Estos usos preposicionales de donde como equivalente del fr. chez los ha reconocido en España (Galicia y León) y en Chile, Perú y Colombia, Cuervo (Disquisiciones filológicas, № 287, 479) y más tarde Henríquez Ureña (RFE, VIII, 358-359). K. Baruch los consigna entre los sefardíes de Bosnia ( $R F E$, XVII, 142) y aclara que "nunca se ha ofrecido una prueba terminante de su uso en los clásicos y menos en los textos medievales". Corominas (RFH, VI, 235) discute el ejemplo ofrecido por Cuervo y piensa que "la extensión actual en España admite que la construcción (uso preposicional) era de origen castellano)". Entre nosotros Alberto Escobar ha dedicado alguna atención al tema (Sphinx, 13, 94-99). De todos modos, es un asunto pendiente de investigación, para la que siempre será de útil confrontación Anna Lichtenhahn, La storia di ove onde di dove da dove (Berna, Romanica Helvetica, 1951, especialmente págs. 135-148), con esmerada atención a la valiosa reseña de Gougenheim (BSLP, XLVII, 159-161), que contiene importantes reparos. Quesada Pacheco (Dic. hist. s.v.) ofrece un testimonio de Costa Rica de 1793.

EMPATAR. Este uso, que Martha Hildebrant recoge de E. Tovar en el Oriente Peruano ("poner el cebo en el anzuelo"), y que de algún modo se enlaza con el sentido que es usado en Venezuela, corresponde realmente a la acepción marinera, de la que parecen derivar los usos americanos de esta palabra. En el Diccionario Marítimo de Fernández de Navarrete se lee, s.v. empatar: "sujetar o unir el anzuelo a un pedazo de alambre o cordel por medio de varias vueltas redondas y fallidas dadas con otro alambre o cordel más delgado" (Garasa Fil. IV, 194-195). En Sejournant podemos leer, sin embargo: "Égaler, être pair, se trouver autant de voix d'un côté que de l'autre".

ESCARAPELAR. Esta es una palabra que merece estudio, no tanto para precisar la etimología cuanto para seguir la evolución de los significados. En salmantino está documenta- 
do escaramondar "pisar los erizos de la castaña": la palabra fusiona ahí un derivado de caryon y de mondar (Cf. García de Diego, RFE, XX, 358-359; RFE, XII, 9-10; Krüger, AILC, IV, 101-102; V, 187 y Gamillscheg; Historia de las lenguas visigóticas). Escarpa solamente aparece por vez primera en el Diccionario de Sobrino, 1705, como término de fortificaciones, procedente del it. scarpa del que también procede el fr escarpe (Gamillscheg, EWFS, 3816). Salvador Fernández piensa en un origen italiano y no gótico. Por cierto, no menciona la palabra Holthause en su Gotisches Etymologisches Wörterbuch, Heidelberg, 1934. Sejournant registra así escarapelarse: "T. familier. Se disputer, se quereller, se battre, se déchirer le visage, s'égratigner". Y con tales valores la tiene registrada Fontecha en Vélez de Guevara y el Glosario de James-Mir en Quevedo. Alcalá Wenceslada consigna dos valores para el ámbito andaluz: a) "Prevenirse contra algo o contra alguno" y "enfurruñarse". García de Diego (Dic. Etim 5957) parte de scarpinarse 'raspar', que garantiza los significados de 'aranar', 'raspar', 'reñir' en esp. y port. y piensa que escarapelar "parece haber sufrido la interferencia de pelar, por un cruce de scarpinare y pilare. Las opiniones son varias y exigen más investigación. No es fácil explicarse el significado de 'dar dentera', 'poner la carne de gallina', que intriga a MH. Por lo pronto, es interesante saber que el rum. scarpiná alienta estas dos significaciones: "rascar" y "sentir comezón, picar" (A. Cioranescu, Dic. Etim rumano, Univ. La Laguna, Tenerife, 1960). Y por cierto, el "sentido figurado de divisa" que escarapela adquiere en el XVIII y al que alude MH se halla bien ilustrado por Sejournant (s.v. escarapela):

"Nœud de rubans, qui se met au chapeau par devise, pour se connoitre dans un combat, dans une bataille, \& aussi pour reconnoitre le parti que l'on suit dans les occasions de tumulte, ou par divertissement"

FESTINAR. El hecho de que aparezcan en el Calila \& Dimna llevó a calificarla de arcaísmo y pedir su inclusión en el léxico oficial. Pagés no trae la palabra, pero consigna 
festinación, con el valor de "celeridad, prisa, velocidad", con lo que repite a Autoridades. Sejournant explica festinación con estas palabras: "Hâte, précipitation, diligence, promptitude". "En general -como apunta Lerner en sus Arcaísmos- "fue palabra de uso poco frecuente y su amplia difusión en América debe explicarse por la temprana influencia de los latinismos de seminario sobre el léxico americano"; que es, en buena cuenta, tesis de Rosenblat. C. J. Córdova la presenta así para el Ecuador actual: "Malversar, malbaratar, gastar precipitada y deshonestamente los fondos públicos". García de Diego registra: festinar 'apresurar'. El Glosario de Jammes registra festinal, usado por el Marqués de Santillana, con el valor de 'rápido'.

FLORIPONDIO. Los léxicos recogen la información arbórea (datura stramonium). El Padre Acosta la describe como de tamaño mayor que las azucenas " $\mathrm{y}$ a modo de campanillas, todas blancas, y dentro de unos hilos como elaucena, y en todo el año no cesa de estar echando flores". Sejournant describe: "Arbre qui se trouve en Amérique \& qui en produit que des fleurs, mais d'une odeur admirable". Pagés nos sorprende con esta acotación: (lat: flos 'flor' y pondus 'grande'): "Arbusto del Perú, de la familia de las solanáceas, que crece hasta tres metros de altura, con tronco leñoso, hojas grandes, alternas, oblongas, enteras y vellosas, flores solitarias, blancas, en forma de embudo de unos tres decímetros de largo, de olor delicioso, pero perjudicial si se aspira mucho tiempo, y fruto elipsoidal, con muchas semillas pequeñas de figura de riñón". En el Ecuador actual: "afeminado", por las mismas razones que $\mathrm{MH}$ explica en su texto.

FOJA. De etimología clara (REW, 3415 y García de Diego 2586): plural lat. folia. Pagés la anota como voz del léxico forense: "hoja de papel en un proceso". Mantiene ese valor actual, pues el Diccionario de argentinismos del Proyecto de Augsburg la reconoce como "hoja numerada de un escrito judicial, contrato, expediente". Y el Diccionario de uruguayismos de Ursula Kühl de Montes aclara: "Hoja numerada de 
un contrato o expediente", aunque agrega que folio es voz más usada.

FORADO. Sejournant nos ofrece su definición con el elocuente laconismo: "Voyer agujero". Pagés le asigna los valores de "agujero, abertura, por lo común más o menos redonda, en alguna cosa, como tela, papel, pared, tabla, etc." En el Vocabulario de Palencia hallamos forambrera, horambrera en el sentido de "agujero" (Dámaso Alonso, RFE, XXVII, 31-34). El Glosario de James acoge ejemplos de forado 'agujero', 'escondrijo' en Berceo y el Conde Lucanor.

FRAZADA. Sejournant dice sencillamente: "Couverture du lit", pero luego, s.v. frazadilla anunciada como dim. de frazada con esta connotación: "Petite couverture usée, mauvaise", que es menos negativa que la versión de Autoridades: "rota y despreciable". Peñalver la presenta como "manta peluda para la cama". Domínguez precisa: "la manta peluda que se echa sobre la cama"; y en frezada remite a frazada. Pagés la deriva de frisar, con textos de Mal Lara, pero remite a Domínguez. En seguida, en frezada remite a frazada y ejemplifica con el romancero; pero en frisar (del fr. friser), y con ejemplos de Cervantes, consigna: "Levantar y retorcer pelillos de algún tejido". Meyer Lübke (REW s.v. fresada 3498). García de Diego (Dic. Etim. 2820) se remonta hasta el ant. prov. flassada 'manta de la cama', ant fr. flassade. No figura como hispanoamericano en el reciente Diccionario que coordinó R. Richard (Madrid, Cátedra, 1997).

FUNGIR. En 1865, en Costa Rica, significaba "desempenar un cargo u oficio". No es clara, por cierto, la explicación que nos ofrece Roig en su Diccionario: "Hablando de una cosa, hacer las veces de"; y menos claro es, en mi sentir, el ejemplo de M. A. Asturias en que se apoya. En Cuba, hacia 1972, significaba "ejercer alguna función". Dihigo y López Trigo propone extenderla como un equivalente de oficiar de y remitirla a oficiar, en su 4 a. acepción, (Boletín Com. Permanente, 15, 150). 
FUSTÁN. A fines del XIX, Gagini la presenta como "prenda de vestir femenina que va debajo de la falda". Calcaño pedía que se dijese directamente enaguas y no fustán. Pagés la registra como americanismo: "Enaguas que usan las mujeres, y cubre desde la cintura, donde se atan, hasta los pies". Alvar (s.v. enagua) cita interesantes textos de Fernández de Oviedo: "Y a este propósito digo que las enaguas son una manta de algodón que las mugeres desta isla, por cubrir sus partes vergonçosas, se ponían desde la çinta hasta media pierna, revueltas al cuerpo". Agrega otros textos de Oviedo, Las Casas y Bernal Díaz. Para Echegaray, procede del cat. fustam 'tela de algodón para forar vestidos'. García de Diego (Dic. Etim. 3000) se remonta a un arrabal cairota Fustat, de donde procederían el cat. fustal 'una tela' y fustán. Sejournant nos ofrece "Futaine, étoffe de fil \& de coton". Bloch-Von Wartburg (Dicc. Etim s.v. futaine) nos aclaran que se trata de una francización del lat. med. fustaneum, probable traducción del griego de los Setenta lina 'tejido de algodón'.

GAGO. Max Leopold Wagner explica que se trata de una "formación onomatopéyica que imita el modo de articular del tartamudo" ( $R F E, \mathrm{X}, 78)$ y le da como equivalentes precisamente 'tartamudo' y 'balbuciente'. Esta idea de la onomatopeya es acogida en su Diccionario por Bloch-Von Wartburg (s.v. gaga), pero orientada la explicación al balbuceo de quienes caen en infantilismo, y aclara: "on retrouve dans d'autres langues cette syllabe gag- avec la même valeur". Peñalver la define directamente como 'tartamudo'; más tarde, Calcaño nos la definirá como 'gangoso', definición que ha de repetir Pagés, quien explicará luego gangoso: "que habla gangueando", con ejemplos de Quevedo y Moratín, para explicar más tarde ganguear de esta manera: "Hablar con cierto extraño sonido a causa de estar obstaculixados los conductos nasales o de ser estos defectuosos o por vicio de pronunciación". Esta acepción parece haber sido la más corriente, pues Sejournant remite a gangos la explicación y ahí dice: "nazilleur, qui parle du nez". En cuanto a la vinculación de gago con gagá, galicismo por 'decrépito', 'chocho', 'senil', ya señalada por Wagner en el 
artículo citado, así como la acepción de 'elegante', 'distinguido', 'alta clase social', que comienza a difundirse en Chile y Argentina y está ya bien asentada en Lima, como advierte Martha Hildebrant, quiero recordar que Giacomo Devoto (Dizionario della lingua italiana) define gagá de esta manera: "Giovanotto che ostenta una eleganza afferrata e vistosa"; la tiene como procedente del fr. gaga ("vecchio remolito"). Dauzat (Dict. Etym. s.v.) da a gaga, a fines del XVIII, como alteración de gateux "par precedé de redoublement enfantin et pour imiter le bégaiement". Littré, s.v. gateux-euse ofrece dos acepciones a) "terme d'hopitaux et d'hospices. Paralytique et infirme, qui rend volontairement les urines"; b) "Aliéné chez lequel l'intelligence est profondement affaiblie" y añade que se caracteriza por el descontrol de los esfínteres. En el Robert podemos leer hoy: "1879, procedente de gateux, documentada, como sustantivo desde 1835 en el argot hospitalario, variante peyorativa de gâteur "qui gate ses draps". Vid. Larousse, de gâter, proced. de guaster, datada en 1080, del lat. vastare 'ravager'. Con ese vastare latino se emparienta el it. guastare 'devastar' y el esp. gastar 'consumir', 'destruir'.

GALPÓN. Hacia 1570 podemos leer en la Relación de Pedro Pizarro la descripción siguiente: "un aposento muy largo con una entrada a la culata de este galpón que dende ella se ve todo lo que ay dentro, porque es tan grande la entrada quanto dize de una pared a otra, y hasta el techo está toda abierta" (Ed. Lohmann Villena, cap. 21, fol. 96). Y a mediados del XVII, Vásquez de Espinosa, en su Compendio y descripción tantas veces citado explica qué son los galpones:

"Salas tan grandes que cada una tiene una carrera de cauallo con muchas puertas, que deuia de ser donde los indios principales y seres llegados de los Reies se aposentaban, al presente seruen de corrales para ganado, por medio de estas dos salas granes se entra en una plaça quadrada, y cercada [...]" (\# 1361) 
La explicación de Granada en su Vocabulario nos ayuda: "Construcción generalmente aislada, con o sin paredes, y el techo de una o dos pendientes. Su principal destino es tener preservados de la intemperie cualesquiera clase de frutos o objetos". La descripción de Pagés podría parecer decepcionante: "Departamento destinado a los esclavos en las haciendas de América". Alvar cita una segunda acepción: "Gobernador con vasallos que reconocen la supremacía de otra autoridad superior". Y un texto de Fernández de Oviedo:

"En algunas partes [...] otros tienen vasallos prinçipales e cavalleros (digo varones, que son cebeçeras de provincias o pueblos con señorío por sí con vasallos), a los queles llaman galpones"

GUA. Calcaño la reco'oce como interjección frecuente en Venezuela y la vincula con el taíno. Pagés explica: "Interjección en el Perú. Se usa para expresar temor o admiración".

GUAPO. Peñalver da para guapear estas equivalencias: "fam., ostentar buen ánimo y bizarría en los peligros". Y s.v. bizarría deja leer: "que tiene valor". Según Domínguez, la palabra significa "animoso, bizarro, resuelto, valeroso, ostentoso, galán"; y para la expresión echar de guapo explica: "echar de valiente, de matón". Calcaño sostiene que es muy raro escuchar en Venezuela esta palabra "en la significación de apuesto y ostentoso, o en la de galán" y sostiene resueltamente: "que para todos guapo es valeroso, bizarro, audaz en sumo grado, capaz de acometer las empresas más difíciles". Frente a esto, pierde eco la solitaria afirmación de Alvarado en su Glosario, donde la palabra tiene esta breve explicación: "Raíz comestible, comparable a un ajo redondo". Pagés aventura el étimo y postula el griego 'animoso, brioso' y se autoriza con este ejemplo del Romancero, que más bien parecería ilustrar el significado de 'valiente, osado, bravucón':

\section{Me fui por fin a la corte donde en tres meses riñeron}


Pagés agrega textos del padre Coloma y de Galdós para ilustrar el significado de 'bien parecido' y un ejemplo de Ramón de la Cruz para justificar 'elegante'. El caso de guapo todavía no es fácil de resolver. Ya en griego kalos se aplica no sólo a la belleza física sino a la bondad moral. Esa actitud estética del pueblo griego se manifiesta de modo contrario en español. Guapo es uno de esos casos; lo propio del alma se aplica al cuerpo; y de ahí bello, bonito, lindo, legítimo, hermoso, defor$m e^{33}$. En el Corregidor sagaz, ms. del XVII, Bartolomé de Góngora recuerda que antiguamente vivía un asistente sevillano, perseguidor de la gente de mal vivir, que solía irse

"de noche a los bodegones del Arsenal disfrazado con un vestido viejo, haciéndose camarada de los guapos, que estaban echando tragos y valentías; y en medio de guaperías, los prendía con la garullada que tenía oculta" (Gallardo, Ensayo, IV, 1210) ${ }^{34}$

En cuanto a la etimología, hasta ahora ha tenido mucha aceptación la etimología francesa patrocinada para guapo, pero en verdad vale la pena estudiar la cosa con calma. O. Bloch-Von Wartburg (Dic. Etim. s.v.) tienen a gouape por "mot d'argot empruntée de esp. guapo 'bravo' " y pop. 'galante, amoroso', que es acepción prestada en época de las guerras de Flandes del picardo wape 'insípido', y éste del lat. vappa 'golfo', 'don nadie'. Aun cuando Baralt no registra guapo en su Diccionario de galicismos, Gabriel Azaïs le reconoce a la palabra gouape un étimo español guapo con las acepciones de

33. Vid. Testimonios en Góngora, Polif. y Sol. II. Cf. además Corominas, Topica Hespérica, I, 304-31 y José Vásquez Ruiz, RFE, XLV, 1962, 299303).

34. Aut. no registra guaperías, que si aparece con el valor de "valentía, baladronada" en el Dic. Encicl. de la lengua española de Roig (Madrid, 1870). 
"magnifique, vaillant, galant" (Dict. des idiomes romans du Midi de la France, Paris, 1877). El propio Littré, cuando trata de gouape, explica: "Terme d'argot. Nomme donné à Paris aux vagabonds sans aveu, sans domicile, sans travail et qui en cherchent que des ocassions de vol. On rattache gouapeur à l'éspagnol guapos, homme qui n'est propre à rien". Y si nos movemos en fechas más recientes, Dauzat tiene a la palabra por procedente del argot español guapo "coupe-jarret" (Dict. Etym. s.v. gouape). El FEW (s.v. gouape) y Gamillscheg (aludido y rechazado por Corominas) defienden la idea de un origen hispánico. Pero Vásquez Díaz ha sugerido un étimo de origen sefardita, pues "el uso en el léxico de los sefardíes de Marruecos bajo la forma wapo sería un indicio precioso". De ahí habría pasado al español, con el significado de "duro, inhumano, seno muy desarrollado", de donde habría surgido el significado de "echado para adelante, ostentoso, ufano". Todo esto estaría relacionado con los rasgos típicos de la mujer bella en la cultura árabe. Esta alusión a la cultura árabe, y sobre todo a la belleza, vuelve a poner sobre la mesa de discusión el tema de los campos semánticos relacionados con la belleza, e invita a renovar la lectura de los trabajos de Otto Duchacék, bajo cuya influencia se han desarrollado interesantes investigaciones ${ }^{35}$. Recordamos que el siglo XVII comienza a advertir grados (superior e inferior) relacionados con la belleza, lo que resulta explicable porque antes no se había alcanzado un nivel cultural que permitiese intuir la necesidad de distinguir grados, clases y tipos de belleza. El campo semántico se va complicando así a la par que enriqueciéndose: 'volver bello', 'embellecer', 'adornar', 'ornamentar', 'aparentar', 'decorar', 'endomingarse', 'admirable', 'maravilloso', 'encantador', 'llamativo', 'altanero', 'envalentonado', 'valiente'. es decir, confusión y conjunción de valores van permitiendo congeniar a conceptos tan diversos, y así vemos

35. Me refiero fundamentalmente a Le champ conceptuel de la beauté en français moderne, Praha, 1960: "La beauté, le beau, la joliesse, le joli" (Philologica Pragensia, II, 1959, 45-49). 
emparentarse y relacionarse conceptos como pompa, esplendor, majestuosidad, lujo, estallido, monumentalidad, escultura, soberbio, acabado, listo, perfecto, impecable, bien proporcionado, bien entallado, fornido, musculoso. Y es que "cualquiera se da cuenta de que, en un determinado momento, los sentidos de algunas palabras son vagos y difieren mucho [...] según los contextos, las situaciones, las capas sociales y aun los mismos individuos: implican numerosos y muy diversos elementos nocionales y extranocionales" (Duchacék, VR, 18, 304). Lo ilustra adecuadamente la gama de acepciones que Autoridades otorga a la palabra, y resultan ahora tal vez muy instructivas las equivalencias propuestas en el Tesauro de Requejo, 1828: Guapear, Fortitudinem ostentare; Guapeza 'Valentía'. En los vestidos: vanitas, ornatus; Guapo 'valiente'. Vid. Galán. Está guapo, Stat habitu ciltuque superbus; Galán, Pulcher, pulitus, escultus, elegans, praestanti corpore homo; Estar muy galán, Elegantis, aut eximis veste conspicuum esse; corporis cultu praestare, tulgere, praducere" 36 .

Sejournant destaca tres acepciones importantes: en primer término destaca la valentía y luego, como veremos, la belleza y la galantería. Nos ofrece, en efecto: "Courageux, vaillant, brave, vigoreux (Fortis, strenuus)". Pero añade: "Signifie aussi beau, galant, bien mis, bien ajusté, brave, magnifique, poli, agréable" todo lo cual en un escueto latín: Elegans, Venustus, Lepidus. Y termina aclarando: "Signifie

36. "Aun siendo significativa la abundancia de pruebas de la presencia del vocablo en dialectos franceses, no lo es menos comprobar que todos los casos de empleo del mismo en el siglo XVII se aplican a situaciones españolas" (Cioranescu, 778). Veamos algunos ejemplos de la época: guapo, 1695: "toutes les rues sont pleines de guapos qui se donnent des cuchilladas", donde cuchilladas acentúa el carácter hispánico de la alusión; guap, 1691: "un jeune homme qui avoit bonne opinion de luymesme et qui étoit un vray guap"; "il y avoit une autre classe de courtisans qui n'étoit composée que de jeunes seigneurs que l'on nommoit guaps comme nous appellons en France les petit-maitres". Esta última aclaración autoriza a pensar que la palabra no era por entonces conocida, o por lo menos familiar, al hablante francés. 
encore amoureux, galant, qui fait l'amour à une femme". Como se ve, todos los campos quedan cubiertos. Pero no hay explicación para muchos de ellos y nada de los dicho confirma la planteada procedencia francesa de la palabra. Por cierto, Echegaray defiende una etimología que llega al griego gauros, y así registra: "cat. guapo" y registra entre varias significaciones, 'animoso, bizarro, ostentoso' "y lucido en el modo de vestir", recuerda galán para el estilo picaresco. Y más adelante, s.v. guapote, adjetivo de uso familiar con el valor de "bonachón, de buen genio o de buen parecer" lo da como derivado de guapo ${ }^{37}$. Con un texto de la Elegía de Castellanos y otro de El Orinoco de J. Gumilla ilustra Alvar la acepción de "Raíz comestible de una planta áracea” (Maranta arundinacea).

GUARAPO. Bebida preparada con el jugo de la caña de azúcar. Vargas Machuca, en sus Milicias, II, 54, registra: "dejarlos gustar del guarapo, que se hace de la miel"; en su Declaración final de nombres propios explica: "es una bebida que se hace de la miel de cañas dulces". Alvar trae una cita del padre Acosta (Procuranda, III, cap. xx, 493):

37. El hecho de que nunca haya faltado bizarro como el significado que encabeza la lista de equivalencias, hace aconsejable dedicar atención a dicha palabra, voz de origen controvertido. Históricamente parece clara la prioridad del it bizarro (s, xiv) que consta ya en Dante; pero la historia de las palabras no coincide forzosamente con la de su aceptación territorial. Por lo general se admite el origen italiano del fr. bizarre, pero no se ha tenido suficientemente en cuenta la diferencia del trato semántico que debería matizar esta observación. Cioranescu ha enfatizado tres campos de valores semánticos distintos: a) "extraño, raro, extravagante" en 1533, escrito también bisarre, sólo se da en francés y en italiano, de donde parece proceder; b) "bravío, valiente", 1574; uso exclusivamente español, que consta raras veces en francés, sin duda por la fácil confusión con el caso anterior. Hacia 1640 Vaugelas señalaba esta discrepancia entre esp. y francés, cuando afirmaba que a los catalanes les chocaba oir que el mariscal de Brezé era bizarro. c) "Ostentoso, elegante" era un evidente hispanismo adoptado también por el italiano. Cioranescu destaca su escasa circulación; sólo se cita un ejemplo del xvi (Brantome) de autor hispanizante. 
"Algunos esclavos de las islas mezclan el jugo del azúcar con ciertas hierbas, de donde sacan una bebida bravísima que ellos llaman guarapo"

En Peñalver leemos: "bebida que se hace con el caldo de las cañas dulces, fermentado". Domínguez, siempre más preciso: "especie de bebida que se hace de los trapiches de azúcar dejando fermentar el caldo de las cañas: es agradable de sabor y saludable". Henríquez Ureña, en desacuerdo con Friederici, la piensa como voz antillana y se remite a ejemplos de Tirso, viajero por Santo Domingo durante el primer tercio del XVII (RFE, XXII, 183). Para Calcaño no sólo es el jugo de la caña de azúcar sino también "el de la piña indígena fermentada y el agua de papelón hervida". Calcaño piensa que no es de origen americano y aventura un probable entronque árabe. Hoy en el Ecuador tiene tres acepciones; las dos primeras repiten lo que venimos diciendo en esencia, sólo que la segunda acepción considera que "utilizada como embriagante" y la tercera supone una "bebida fermentada hecha de la composición de hierbas diversas de principios activos narcóticos y otros ingredientes de efectos altamente embriagantes y tóxicos".

MACANA. Todavía ha de dar trabajo esta palabra. Los textos antiguos nos la presentan como arma contundente; en 1589, Juan Pérez de Peralta en su Tratado del descubrimiento de las Indias nos habla, en general, de que las armas de los indios "eran flechas y porras, y macanas y espadas de palo metidos pedernales por filo para que cortasen" (Cap. II). Bernardo Vargas Machucha, en su Milicia y descripción de las Indias, 1599, alude a los macanazos para referirse a los golpes dados con el instrumento:

"y como vieron la ocasión tan buena, el soldado sin armas, y el perro atado, acordaron ponerlo en ejecución descargándole un macanazo, que es arma que ellos usan" 
Mucho más descriptiva es la explicación que en el XVII nos ofrece Vásquez de Espinosa porque nos dice claramente que la macana "es de palo gateado muy curioso" (\# 180), y párrafos más adelante, aclara hablando del arma:

"Es tan rezio que si no es aserrándolo con mucho trabajo, no ai hacha que le pueda entrar; es la madera más peregrina que se halla en el mundo, el coraçon de palo es cristalino, que no ai jaspe que le iguale, y es incorruptible" (\$ 243).

En realidad, es lo que destacan los lexicógrafos extranjeros; así Sejournant declara: "Espèce de sabre ancien des Indiens, fait d'un tois très dur \& garni au long des pierres à fusil; il était aussi tranchant qu'un sabre du plus fin acier, dont ces peuples en connaissaient point encore l'usage". Muchos de estos datos los reúne Granada en su Vocabulario II, 79, al presentar macana como "Arma ofensiva de los indios, a manera de garrote variamente dispuesto para hacer más destructores los efectos de su golpe. Añade seguidamente que se trata de un "garrote corto, con manjía". Cree que la palabra deriva del mex. macahui, 'espada de madera': de maytl 'mano' y quauitl 'madero', que es la etimología defendida por la Real Academia. Más tarde, en sus apuntamientos nos ofrece una atingencia:

"Se ha supuesto erróneamente que macana, porra y espadón de madera de dos filos, que usaban los indios de las Antillas y en todo el continente, viene de la voz mexicana macahuitl, maytl 'mano' y quaitl 'madero', etimología que parece algo rebuscada [...] Sin embargo, Fray Bartolomé de Las Casas asevera con insistencia que macana es nombre que dan los indios de la Española al arma que se trata"

Ilustrativos son los textos con que Alvar registra la acepción de 'arma guerrera' (pp. 229-232, y ciertamente interesantes los que respaldan la de "palo utilizado en las labores del campo", con citas de Oviedo, Las Casas y Jacinto de Carbajal. 
MAZAMORRA. Palabra merecedora todavía de mucho estudio. De las cuatro acepciones que le asigna Autoridades, la cuarta, referida al Perú, es la única que explica la inclusión de mazamorra en el Diccionario de Sejournant, que la presenta como una "Espèce de manger, qui se fait dans la Pérou entre les pauvres gens \& qui est composé de farine faite de blé de turquie, délayée avec du sucre ou du miel \& de l'eau"; explicación que recoge alguno de los datos de $A u$ toridades $^{38}$. Granada explica que se trata de "maíz partido y cocido, regularmente blanco, el cual, dejándolo enfriar, se come con, o sin, leche y azúcar"; recuerda también las diversas maneras que los pobladores "imitando a los indios, comiéronle y aderezáronle de modos diversos" al maíz; una de ellos "en tamales, estilo de Méjico; con ají, canela y azúcar, envuelta la masa en chala (hoja de la mazorca) y cocida en cacerola con agua, con leche o sin ella, y con azúcar, o sea la mazamorra". Cuervo ha recordado (Cast. en América) "el nombre de mazamorra con que la gente de mar llamaba al potaje hecho de pedazos de bizcocho hervidos en agua", y ofrece para respaldo este texto de Las Casas (Hist. de las Indias, III, 128):

"Pudrióseles tanto el bizcocho, y hinchóseles de tanta cantidad de gusanos, que había personas que no querían comer o cenar la mazamorra que del bizcocho y agua puesta en el fuego hacían".

En el Paraguay, la mazamorra es un "plato elaborado esencialmente con maíz blanco y que puede ser salado o dulce según su preparación" (Granda, op. cit. 325)

MONTONERA. Granada apunta: "Grupo o conjunto irregular de gente de caballería que guerrea contra las tropas del gobierno de un estado". Pagés vincula la palabra con el mundo

38. Como es sabido, la redacción de las papeletas concernientes a la letra M estuvo a cargo del peruano Diego de Villegas y Quevedo, como oportunamente advirtió Guillermo Lohmann Villena. 
americano en concreto: "Grupo o pelotón de gente a caballo que guerrea contra las tropas del gobierno en algunos de los estados de América del Sur". Y se vuelve más explícito s.v. montonero: "Perú, guerrillero". El Diccionario de hispanoamericanismos de Renaud Richard anota hoy: "Amontonamiento de personas o animales, que forman un entrevero desordenado y peligroso" y lo relaciona con el Río de la Plata.

MOROCHO. No la registra Autoridades. Aceptación general sobre su etimologia: procede del quechua muruchu (García de Diego lo da como "maíz tostado" y Echegaray, sin arriesgar etimología, había consignado: "Metafórico familiar americano. Tratándose de personas, robusto, fresco, bien conservado". Pagés la inscribe como "maíz morocho", sin especificación de americanismo y la da como procedente de moro, repitiendo las ideas de Granada, a quien no nombra; seguidamente, como americanismo y alusivo a personas, lo registra en las acepciones de "robusto fresco, bien conservado", que es la acepción del ejemplo de Palma citado por Martha Hildebrant y acogido por el DRAE. Resultan curiosas las acepciones que ha ido acogiendo la palabra. Alvarado (Glosario, III, 171), tras anunciar la significación venezolana de "gemelos, mellizos del mismo sexo", recuerda que en Honduras "tómase por labi hendido (personas) o desportillado (cosas)"; nos entera asimismo de que los meses de junio y julio son llamados los morochos porque en ellos "siendo crudas las lluvias en el llano se interceptan o entorpecen las comunicaciones entre los pueblos y lugares y se encarecen los víveres". Y nos recuerda que, por entonces, Tener el hambre morocho significaba "tenerla con exceso". A fines del XIX Granada en el apartado dedicado a tupí de sus Apuntes lexicogáficos dice: "Maíz de grano duro y de color morado, con alusión al del indio de la generación tupí. Por otro nombre, generalizado en América y en España, morocho"; recuerda el texto del Inca Garcilaso ("los indios llaman muruchu al maíz duro"), y aventura esta afirmación: 
"Es posible que el muruchu quichua haya tenido origen del morocho castellano, como ha sucedido con otros nombres que de boca de los españoles han pasado al habla de los indios, con la modificación correspondiente a la fonética de las respectivas lenguas aborígenes. Esta conjetura se fortifica considerando que el maíz morado-oscuro, según el mismo Garcilaso, tiene el nombre de cullizara, en quichua, a distinción del blanco y tierno llamado capiazara el cual, por ser de regalo, denominaron en especial capia"39.

Algunas de estas ideas las había adelantado Granada, al afirmar que muchas voces como baquiano, chicha, cimarrón, cacique, baquia y baqueano, macana y yuca eran en realidad "voces haitianas variamente ajustadas a la fonética castellana", y al sentenciar que "no son precisamente americanismos, sino voces legítimamente españolas, de antiguo abolengo, las que desusadas o muertas en el habla peninsular, han sobrevivido en América". Calcaño defiende la acepción de "gemelo y mellizo" y afirma desconocer en qué zonas americanas se dan esos valores asegurados por el diccionario académico "al maíz que se distingue por su dureza y a la persona robusta, fresca [...]". Y sentencia: "En las repúblicas del Plata y en el Perú morocho significa "moreno y deriva del latín morus", y repite lo que decía Granada sobre la Mauritania.

Hoy en el Ecuador morocho "se aplica a personas de avanzada edad, [...] todavía en uso de sus facultades físicas o intelectuales". Y el Diccionario Hispanoamericano de Renaud lo considera un adjetivo: "De tez morena" y que "a veces es

39. Apuntamientos sobre lexicografía americana, Bs. As. 1948, 105-106. Anteriormente, en su Vocabulario rioplatense, Granada habia sostenido que morocho derivaba de moro "con alusión al color natural de los habitantes de Mauritania". Lafone y Quevedo opina en sus Catamarquenismos que muruchu viene de la voz indigena musu 'manchada'. 
un eufemismo por persona negra". Cómo explicar esta variedad de acepciones y justificar las connotaciones de "robusto, duro, oscuro", tal vez fáciles de asociar con las de "doble y mellizo". Es tarea para los interesados en el léxico hispanoamericano.

NO MÁS. He aquí un atractivo estudio monográfico. "En América del Sur -dice Henríquez Ureña- no más es una muletilla que puede traducirse de muy varios modos y que suele escribirse como palabra sola: nomás" (BDH, IV, 1937, 61). En español, a diferencia del rumano, "no más no se ha fosilizado totalmente y no se ha gramaticalizado completamente" (Gazdaru, Fil. I, 1949, 23-42). Nosotros colocamos la expresión después de la palabra a que se refiere, y convendría arriesgar una investigación sintáctica al respecto (Cf. Kany, HR, XIII, 1945, 72-79; Keniston, The syntax of Castillan Prose, Chicago,1937, 40.735)

PALANGANA. Según Granada (Vocabulario rioplatense, II. 129) es el sust. o adj. aplicado al "descarado y algo sinvergüenza"; contradiciendo a Paz Soldán, tiene por "más verosímil que tenga afinidad con la cara redonda, grande y lavada, de la palangana; porque realmente es preciso tener cara para ser un palangana". El razonamiento está, como se advierte, alejado del carácter habitual con que Granada suele tratar estos asuntos. Pagés no trae palangana, pero sí palanganada, que explica así: "América, ponderación, jactancia”. Hoy, para Costa Rica, Quesada Pacheco nos da: "flojo, falto de decisión", después de que en 1892 significaba "presumido, jactancioso".

PANTORRILLA. Pagés la registra como americanismo, fig. y fam. y la explica: "vanidad ridícula que distingue a una persona". Y seguidamente registrada pantorrilludo: "América, vanidoso, jactancioso".

PECHUGA. Veamos: Pagés la da por "parte blanda" que iuce el ave en el pecho a un lado y otro del caballete"; la definición se inspira tal vez en Peñalver, que decía: "pecho del 
ave que está como dividido en dos, a una y otra parte del caballete" ilustrada con un texto de Moreto. Para Domínguez, la explicación se reduce a "cada una de las dos mitades del pecho de un ave". Sejournant acoge dos acepciones, una de las cuales dice: "golpe dado en el estómago de un hombre o una mujer". Ya adentrado este siglo, la cosa cambia. Max L. Wagner, reseñando un libro de Lemos sobre léxico ecuatoriano, anuncia "abuso de confianza que se nos dispensa", "impertinente, descocado" (RFE, X, 79)

PEPIÁN. Compite con pipián. La leemos en una lista del Obispado de León, en Nicaragua, en 1746: "variedad de cucúrbita comestible, más pequeña que el ayote y de cáscara rayada". Sejournant nos obsequia con esta detallada explicación; s.v. pipián: Fricasée indienne, composée de mouton, de poule ou poulet d'Inde, de gros lard, d'amande pilée, avec fortes épices, sourtout du oivre rouge. Lat. India condimenti genui". Parece que hubiera leído a Peñalver, que nos remite a pipián: "guisado usado en Indias, que se compone de carnero, gallina, pavo u otra ave con tocino gordo y almendra machacada". Pagés también nos da pepián, pero consagra la definición s.v. pipián y repite textualmente a Peñalver, pero ilustra con un texto de Moreto: "Ven a la mesa! Mira aqueste pipián / que el pimiento bermejea", donde se alude al condimento, como en Sejournant.

PETATE. En su texto de 1589, Suárez de Peralta nos deja leer este fragmento:

"y todo el suelo de la sala estaba esterado con unas esteras hechas de lo mismo que los asientos, que allí llaman petates y colgados por las paredes muchos ídolos". (Cap. II, ed. cit. p. 2) ${ }^{40}$.

40. En el Indice de palabras, Suárez de Peralta vincula petatl 'estera' y ofrece los nombres mexicanos para las esteras de palma, de cana y de juncia y juncos gordos. 
Alvarado nos da: "estera de palma de junco" y la deriva del azteca petatl; Calcaño establece que procede del taíno (\# 1049). Pagés la da procedente del mex. petlatí 'estera' y la explica de este modo: "Esterilla de palma que se usa en los países cálidos para dormir sobre ella". Para la expresión lía petates tendremos en cuenta otras acepciones (no referidas específicamente a América en el Diccionario): "Lío de la cama y la ropa de cada marinero, de cada soldado en el cuartel y de cada penado en su prisión". Otras acepciones acogidas: Equipaje de cualquiera de las personas que van a bordo". Liar petates suele explicarse como "mudar de vivienda". Ninguna de estas acepciones alcanza a explicarnos la escueta referencia que nos da Sejournant: "Voyez Estafador", voz bajo la cual solamente nos da lo esperable en español.

PIQUE. La información de Granada en su Vocabulario es interesante, porque no remite a ninguna otra voz y define prontamente: "Insecto que hay en Misiones, Paraguay, Chaco, etc., el cual, introduciéndose por los poros del cuerpo, si no se le extrae a tiempo, se multiplica prodigiosamente, corroyendo la carne". Por otro nombre en América nigua, no usado en el Río de la Plata". Sejournant, s.v. nigua agrega algunos datos interesantes: precisa los pies como objetivos del insecto y alude a las complicaciones:

"Espèce de vermisseau qui se trouve aux Indes, qui saute comme un pouce, \& se fourre entre cuir \& chair dans les orteils de ceux qui marchent nud pieds, de façon que quelquefois il faut appliquer le cautère, ou même couper la partie" ${ }^{\prime 41}$.

Alvarado y Calcaño son los únicos que conjeturan procedencia; para Calcaño (s.v. nigua) la voz no es indígena sino

41. Antonio de Ulloa, en sus Not. amer, también alude a estos contratiempos: luego de mencionar al insecto "llamado pique o nigua, cuya incomodidad es frecuente, como el peligro de que se corre despues de la extracción, si por casualidad se moja el pie". 
de procedencia árabe, aunque no dice cuál sea la palabra árabe de que provendría nigua; para Alvarado (Glosario, I tomo), es voz taína. Nadie vuelve a hablar de pique, pero Alvarado agrega algunos datos que sirven para identificar al insecto en cuestión, pues nos advierte que se diferencia de la pulga "en tener blanca la parte posterior del cuerpo y la boca armada de una trompa larga" y nos informa que "se halla hasta 2000 metros sobre el nivel del mar y la hembra vive parasíticamente en los mamíferos" ${ }^{\prime 2}$. Vargas Machuca (Milicia, II, 218) las describe como "un género de pulgas que se meten en la carne de los pies, y se cria mayor que una lenteja, en el entretanto que no se saca de fastdio". Alvar da nigua y recuerda un fragmento de El Orinoco, II, cap. xvi, 407 de José Gumilla, que dice:

"Las niguas son plaga muy universal [...] En el Paraguay y otras provincian llaman piques"

Luego ofrece útiles testimonios de Pedro de Aguado, Las Casas, Oviedo para ilustrar la acepción 'insecto' y un ejemplo de Juan de Castellanos para la acepción "cosa pequeña".

PISCO. En Alvarado, (tomo I, 294) corren dos acepciones: La primera alude a la voz quichua pisco 'ave' y se explica como "pavo en la Cordillera". La segunda dice sencillamente, sin alusión a etimología alguna: "Ebrio, en la Cordillera" y menciona el refrán "Con el miche y con el pisco pasan las penas del risco", en el que piensa hay una alusión "al afamado aguardiente de Pisco, designado en Chile con el mismo nombre". Dos acepciones también ofrece Pagés: la primera, alusiva a Chile y Perú menciona: "Aguardiente superior fabricado en Pisco, lugar peruano"; la segunda, exclusivamente peruana: "Botija en que se exporta esta aguardiente".

42. De las tres acepciones para pique registradas por el Dic. de Hispanoamericanismos de Renaud Richard ninguna menciona estos significados, y menos las acepciones consignadas para nigua. 
PLAYA. Los diccionarios registran la palabra desde 1492. Corominas la tiene por procedente del. lat. plagia y defiende la siguiente evolución: "lados", "costados", "ladera", "costa marítima". Su uso como sustantivo o adjetivo no es firme y Nicolás Marín ha ofrecido un texto del Conde de Torrepalma, de 1748 , donde la palabra es usada con los dos valores. En Venezuela, hacia 1828, su valor es el que recoge Alvarado: "En los mercados y mataderos es el lugar destinado a exhibir y ofrecer a la venta frutos, comestibles o ganado para el consumo" (Glosarios del bajo español en Venezuela, Caracas, 1954, vol. I, 389). En la Argentina se da a la palabra "sentido de explanada, pista o campo" y así alude indistintamente a playas de estacionamiento para automóviles, a playas den juego para niños y a playas de maniobras en las estaciones de ferrocarril" (Berta Vidal, Fil, I, 106-107). En el Paraguay la palabra alude a una "superficie llana y despejada" (De Granda, SHLP, 326).

PONCHO. Los diccionarios antiguos nos deparan datos diversos y confirman que por lo menos la acepción corriente en América fue largamente desconocida en la Península. Hoy María Moliner recuerda que la acepción americana es la única vigente en España y lo explica "tal vez por tratarse de un vocablo de la jerga marinera". Los diccionarios antiguos nos deparan rica información. Peñalver registra la palabra como adjetivo: "manso , perezoso, dejado y flojo"; como segunda acepción consigna: "Sayo sin mangas que se lo pone por la cabeza a modo de casulla". Domínguez repite textualmente a Peñalver y sólo agrega al final "[...] casulla o cosa semejante". Granada recuerda el araucano pontho (aunque pone de relieve una anterior observación de que "casi iguales o mejores títulos que el quichua y el chibcha puede alegar en su favor el araucano"). Su definición es clara: "Manta cuadrilonga, con una abertura en el medio a propósito para introducir por ella la cabeza, a fin de que aquella quede pendiente de los hombros, cubriendo pecho y espalda. Usalo habitualmente la gente 
de campo" (Vocab. II, 159) ${ }^{43}$. Calcaño nos ofrece algunos ejemplos desconcertantes: "gallo poncho, gallina poncha, pollo poncho" para decir que no tiene cola. Es impropiedad. Lo autorizado es decir reculo ( $\$ 1219$ ). Alvarado consigna tres acepciones: a) Corto (hablando de vestidos): "los pantalones le quedan ponchos"; b) Rabón, reculo: "Hablando de animales, se aplica de ordinario a las gallinas de Persia, que carecen del hueso cócxix (sic) "[...] o bien al Chigüire (Hydrochoerus Cpaybara) a causa de su cola rudimentaria"; c) "Manta corta, esclavina. Objeto usado en los pueblos de la Cordillera y de los llanos de Arauco". Remite a manta y lo da como frecuente en Chile y Colombia. Pagés trae varias entradas; repite la etim. araucana de Granada y aclara que pontho significa 'ruana', 'capote de monte', y acoge también las acepciones de "manso, perezoso, dejado, flojo". Para este poncho 'flojo' parecería haber acuerdo sobre la etimología: García de Diego (Diccionario 2980 lo da procedente del lat. fungidus 'fofo' (de fungus 'hongo' procede el gall. foncho 'hueco, hinchado' y el cast. poncho). La discusión, en cambio, alcanza a la etimología de poncho 'manta'. Cierto es que Morínigo propuso para la palabra un origen mediterráneo, fiado en que aparecía en un texto de Alonso de Santa Cruz, de 1530, donde se aludía a "ponchos y orejeras". Fernando Casullo favoreció la tesis con la historia de la prenda misma (BAAL, XXIX, 1964, 85$100)$, y por cierto obtuvo el respaldo de Corominas en el DCELE. Pero queda todavía sin respuesta la observación de Rolando Laguarda (Boletín de la Comisión Permanente, 18, 1973, 281-284); ahí sostiene -a la luz de "otros escritos coetáneos correctamente leídos"- que la lectura adecuada debe ser planchas $y$ orejeras. Y cita un texto anterior de julio de 1528 , en que Luis Ramírez, hablando de los guaraníes dice:

43. Ha de tenerse en cuenta la rica ejemplarización con que Friederici ilustra el caso de esta palabra. Granada (ibid., p. 22) ha dedicado algunas observaciones a expresiones como Arrastrar el poncho, Pisar el poncho, que convendría tener en cuenta en las investigaciones próximas. 
"ellos traen mucho metal de oro y plata en muchas planchas $y$ orejeras y en achas con que cortan la montaña" (énfasis mío)

Y más adelante en el mismo texto anuncia: "estos yndios vimos traer muchas orejeras y planchas de muy buen oro y plata". Según Laguarda, la de Morínigo ha sido una lectura inadecuada, y robustece su interpretación el hecho de que en los Comentarios de Alvar Nuñez Cabeza de Vaca se lee que los guaraníes comprobaban en los pueblos por ellos saqueados "muchas planchas de plata y oro, y barlotes, y orejeras, y brazaletes". Por lo menos, esto obliga a repensar. Tengo a la vista un texto de Vásquez de Espinoza (Compendio y descripción, § 941) donde leemos:

"El trage de los Indios del Obispado, y Gouernación de Santa Marta son camisetas y mantas de algodón pintados, traen orejeras de oro".

Válida permanece la afirmación de Morínigo en el sentido de que Alonso de la Cruz tenía por conocida a la voz y no creyó necesario explicarla. Para Laguarda, la tesis de Morínigo es absurda frente a la realidad climática, pues "los indios del alto Paraná nunca usaron ponchos debido a que el clima les permitía andar casi enteramente desnudos" (ibid., $283)^{44}$.

PROLIJO. El dato de Pagés resulta interesante porque ofrece un texto de Tirso con el valor de "demasiado cuidadoso y esmerado", que es significado prevaleciente en América,

44. Que la acepción 'flojo' era la imperante lo ratifican los diccionarios extranjeros. Sejournant se limita a consignar: "Paresseux, mou, lâche, nonchalant", y lo ratifica con el equivalente latino: Iners, desidiosus. Echegaray no arriesga etimología, pese al título de su Diccionario: "Manso, perezoso, dejado, flojo"; pero agrega: "Sayo sin mangas que se pone por la cabeza" y anade el aumentativo ponchón, sin aciarar si vaie por 'muy flojo' o por 'manta grande'. 
zona no desconocida para el dominico. Sejournant aclara: "Signifie aussi excessif en tout, qui a trop de soin".

PUCHO. Granada (Vocab. II, 162-163) lo refiere al quichua y arauc. puchu: "Sobra o resto, y también lo que vale muy poco y se desprecia"; ofrece ejemplos de 'una sobra', 'resto', 'una nada', 'poca cantidad', 'cosa despreciable'. Lo da como corriente en Bolivia, Chile y Perú y acata la explicación de Rodríguez: "para expresar el resto del cigarro" o bien "para ponderar lo poco que se estima a una persona". Pagés la acoge como americanismo: "la punta o colilla del cigarro, y por extensión cosa de poco valor". Añade que figuradamente puede significar "pequeña cantidad que se da de una cosa". No se discute el origen quechua de pucho, pese a las objeciones formuladas por Lenz, partidario de un origen mapuche. Buesa Oliver registra a pucho como quechua, (Indigenismos léxicos del español, Madrid, 1965, 58), pero seguidamente reconoce su dificultad para deslindar estas voces quechuas y aimaras (ibid., 67). Son interesantes las reflexiones de Laguarda, "Algunas observaciones y sugerencias sobre la labor etimológica” (Bolet. Com. Perm. tomo citado, 299-300).

PULPERÍA. Peñalver explica así: "Tienda en las Indias, donde se venden diferentes géneros para el abasto"; luego define pulpero como "el que tiene tienda de pulpería en los reinos de las Indias"; agrega, por cierto, una segunda acepción: "pescador de pulpos". Domínguez repite textualmente las acepciones a propósito de pulpero, pero se explaya en pulpería: "Tienda en las Indias donde se venden diferentes géneros para el abasto: como son vinos, aguardientes o licores, y géneros pertenecientes a droguería, buhonería, mercería y otras: pero no paños, lienzos y otros tejidos" y ofrece un texto del Inca Garcilaso; luego s.v. pulpería, a la que tiene por derivada de pulpo, repite textualmente a Domínguez, pero ofrece un texto de la Recopilación de Indias. Cuando nos decidimos a trabajar en la etimología, surgen cruces con pulque, y por eso vale la pena detenerse. En su estudio Pseudokaraibisches (ZRPh, 33, 513-535) Leo Wiener estudia algunas 
voces americanas: pecarí (518-522), la planta del magüey, para lo que se remonta a las Décadas de Pedro Mártir, y explica que de esa planta se extrae el pulque, que se vendía en un sitio llamado en México pulquería "sonst aber im Spanischen Amerika pulpería" (527). Wiener se remite seguidamente a la Recopilación de Solórzano (tomo I, 142), recuerda la vinculación establecida por Garcilaso con pulpo y acude, finalmente, a Pedro Simón Abril, en su primera parte de las Noticias historiales (Cuenca, 1637) para recordar que en su Vocabulario se lee s.v. pulpero:

"Pulpero es el que vende en público frutos de la tierra, y de Castilla, fuera de ropa, particularmente cosas de comer, no guisadas, y llamáronle pulpero a los principios de estas Indias, porque como auia pocos que usassen este oficio, acostumbraron los que lo usavan a vender en sus tiendas trozos destos y como tenían muchas cosas al modo que los pulpos tienen muchos pies, les llamaron pulperos, ya por vocablo más grave les llaman tratantes, a la tienda destos dicen pulpería".

Una ley impresa en 1623 fija las condiciones en que se desenvuelven las pulperías (Recop. Lib IV, título xviii, ley xiv); y recogemos la noticia temprana, en 1586 (ibid., ley xvi) de un pulpero que negocia vino cocido. Wiener piensa que, en los inicios del siglo, el pulpero fue un comerciante de frutos y extractos frutales, es decir de la pulpa: "Man hatte pulpa cassiae, pulpa colocynthidis. Im portugiessischen Wörterbucher staht a polpa do figo columel, polpa de canafistula concretum cassiae atramentum". Y los vocabularios italianos registran: polpa di ficchi secchi. Litré (lo recuerda Wiener, 527) cita para el siglo XVI que lo de adentro "n'est qu'une poulpe, comme en nos figures". Estamos, pues, para Wiener, en el mundo de los juegos y las drogas, en el campo de la farmacopea en que jugos aromáticos y jarabes se juntan en el Libro Segundo de Pedro Mártir. Y en eso funda su interpretación de pulpa como antecesor de pulque. Cuando Sejournant se enfrenta a pulpería la define como "Boutique dans les Indes, où 
l'on vend toutes sortes de marchandises, excepté les toiles, les draps \& les étoffes". Luego, s.v. pulpero se limita a presentarlo como "Marchand qui tient boutique dans les Indes de toutes sortes de vivres, de liqueurs \& de marchandises excepté les draps, etc.". Ni una alusión al pulque, actitud que mantendrá Sejournant al explicar s.v. pulque, donde no habrá mención alguna de pulpero ni de pulpería: "Le jus ou suc de manga, grand arbre qui croit dans les Indes, \& dont les Indiens font leur brevage ou boisson, en y joignant d'autres ingrédientes". Pulpería y pulque comparten desde hace tiempo la reflexión lexicográfica y aparecen vinculadas cada vez que se intenta averiguar la etimología de pulpero. Del pulque habla Vargas Machuca, 1599, al recordar que del magüey "cogen el zumo y caldo que de él sale, y que no es poco, y de él hacen miel cociéndolo; y también vinagre y vino que llaman pulcre en la Nueva España; esta bebida emborracha más al indio que la chicha u otra alguna" (Descripción de las Indias, Lib IV). Vázquez de Espinosa (Compendio y descripción), a mediados del XVII, recuerda que en 1610, había en Chuquisaca "42 pulperías en que se vendían mantenimientos por menudo" ( $\$ 486)$; en otro lugar ha explicado la existencia de "una mata, o arbolillo mysterioso, llamado magüey" del que los indios hacen "su vino, que llaman pulque ", y confiesa haber publicado en 1623 un libro Luz y gloria del cielo, donde explica la historia de dicha bebida. Calcaño (§ 631) acude a Pedro Simón Abril y al Inca Garcilaso y, con intemperancia habitual, afirma que el hecho de que cuando escribe todavía se vendan pulpos en la pulpería es suficiente para afirmar que "nada tiene que ver con el mexicano pulque ni con su derivado pulquería" la palabra que estudiamos. Alvarado, tras dar el equivalente de 'abacería' nos ofrece un hermoso texto de Depons, que transcribo:

"Hay en la Tierra Firme tiendas conocidas con el nombre de bodegas y en otras partes con el de pulperías. Surtimiento consiste en loza, vidrios, quinca1la, herramientas, vinos, azúcar, jamones, manteca, aceite, frutas secas, queso y guarapo, etc. Tienen 
sobre las tiendas la ventaja de no ser sujetas a quedar cerradas los días de fiesta y domingos" (Glosario de voces indigenas, 1953, 298)

Luego anuncia tajantemente que pulpería "es corrupción de pulquería, es decir puesto donde se vende pulque, voz ésta que sin embargo no ha sido adoptada en Venezuela"; y cita un fragmento de la Política Indiana que alude a cédulas de 1631 en que se ordena

"que en cada ciudad o villa se apuntasen y señalasen ciertas tiendas, de las que en Castilla llaman de Albacería en las Indias de Pulpería, o Pulquería, de pulque, que es una bebida que usan mucho lis indios de la Nueva España" (Lib IV, I, 19)

Este texto debe haberlo tenido presente Granada cuando afirma que la pulpería es un "compuesto de abacería y taberna" y cuando defiende su procedencia de pulque; sin embargo, en su Vocabulario (Vol. II, 163-166) nos ha ofrecido estas definiciones, s.v. pulpería

"Casa o rancho donde se vende por menor vino aceite, grasa, yerba, azúcar, velas de sebo, caña, cigarros ordinarios y otras cosas semejantes. La casa en que se despachan objetos análogos de calidad superior se llama almacén de comestibles y bebidas o simplemente almacén, aunque también suele dársele el nombre de pulperia, particularmente en los pueblos de la campaña, así como cuando se halla establecida fuera de las poblaciones o en medio del campo".

En lo que Granada no coincide con Solórzano es en la etimología; para él es buen argumento el que las leyes de Indias cuando aluden a las tiendas donde venden pulque hablan de pulquería, y cuando tratan de aquellas que se ocupan "del abasto o mantenimiento de las poblaciones, no omiten decir pulperias"; y para reforzar su opinión se acoge a un texto de Gaspar de Escalona: 
"Pulperías son en el Perú tiendas, mesones o tabernas donde se venden algunos mantenimientos, como son vino, pan, miel, queso, manteca, aceite, plátanos, velas y otras menudencias" (Gazophilatio regum peruv.).

Que las correspondientes pulperías del Río de la Plata eran distintas se encarga de aclararlo el mismo Granada: en realidad "suelen tener ponchos, bombachas, chiripás, botas, géneros, drogas, recados, arreos y otras mercaderías Pero se les llama pulperías precisa y determinadamente por lo que tienen de abacería y taberna". Y agrega como sentencia: "si en una de esas casas no se despachasen mantenimientos y bebidas, nadie le daría el nombre de pulpería". Mucha confusión, como se ve. Lenz, que ubicaba las pulperías chilenas "en los distritos mineros i las salitreras" del Norte, y "y en el Sur, sobre todo entre Indios", acepta entre sonrisas estos supuestos vínculos etimológicos entre pulque y pulpería: "más se parece a mala broma que a etimología" afirma, pero cierra la frase con esta confesión: "pero no conozco otra mejor". Sigue siendo significativo que Friederici solamente acoja pulpería y anuncie que toda está explicado bajo pulque, cuyo dato más antiguo es de 1524 en la carta de Hernán Cortés.

QUINCHA. Pagés la reconoce como voz de origen quichua, con vigencia en América meridional: "Tejido o trama de junco con que se afianza un trecho de pared de paja, totora, cañas, etc.". Y para Chile reserva esta otra acepción: "Pared hecha de cañas, varillas $u$ otra materia semejante, que suele recubrirse de barro y se emplea en cercas, chozas, corrales, etc.". Luego, s.v. quinchar, a la que ubica también en América meridional: "cubrir o cercar con quinchas". Parte de esta definición parece inspirada en Granada, que arriesga la etimología del quichua khincha y alude a su difusión por Chile y Río Grande del Sur. Esa etimología está también aludida en Bertonio, s.v. quencha, donde se explica: "estera de enea, caña o totora atada o trauada con soga de hicho o con cordel 
de lana"45. La misma procedencia asigna Alvarado (Glos. Indigena, 304) que aclara, tras repetir a Granada y a Arona: "En el Perú, pared campestre de caña y barro". Pero sin duda la descripción más minuciosa sobre quincha nos viene proporcionada por el padre $\mathrm{Cobo}^{46}$ :

"En los Llanos y costa de la mar hay dos suertes de casas, unas de bahareques y otras de tierra y adobes: sobre aquéllas tienen por paredes y cerca un encañado muy cerrado y tejido a modo de zarzo, el cual hincando en el suelo un orden de cañaz bravas o de varas muy juntas, y a dos codos del suelo, poco más o menos, atraviesan una caña por medio a modo de trama, dejando a cada lado la mitad de las dicha cañas hincadas, las cuales como cairel cruzan por encima de aquella caña atravesada, y a otro tanto trecho atraviesan otra; y desta suerte, con tres o cuatro que atraviesas, con las cuales van cruzando $\mathrm{y}$ entretejiendo las que suben derechas, queda hacha la pared de dos estados de alto, poco más o menos; y esta manera de paredes llamamos bahareque, tomado el nombre de la isla Española o de Tierra Firme, que los naturales deste reino no la llaman sino quencha."

RAJAR. Pagés la acoge como uso familiar y figurado: "Decir o contar muchas mentiras especialmente jactándose de valiente y hazañoso". Ofrece una cita de Trigueros, que reproduzco porque ilustra sobre el régimen sintáctico: "Escandalizábame yo de oirle rajar así contra todo el mundo, y no dejando que prosiguiese, le dije etc. [...]". Entre nosotros, lo frecuente es rajar de y no rajar contra. Sobre la etimología,

45. Vocabulario de la lengua aymara, 1612. Cito por ed. X. Albo / F. Layme, Cochabamba, 1984.

46. Cito por ed. F. Mateos, Madrid, BAE, 1956. Historia del nuevo mundo, 1653, Libro XIV, cap. 3. Desgraciadamente, no he podido hallar el estudio de Rolando Laguarda, "Historia de los americanismos quincha y bajareque, publicado en 1958, ignoro dónde. 
Meyer Lubcke (REW 6989, 7001) defiende la procedencia del lat. radúla, en oposición a García de Diego (Dic. Etim. 5392, 5395) que prefiere el lat. radiare 'rayar', que da cast. rajar 'hender'. Sejournant, en una segunda entrada, registra: "Par allusion signifie: Dire, conter des menteries, vanter sa bravoure, se louer soi-même".

RANCHO. En el Vocabulario rioplatense de Muñiz, 1845, se lee: "casa cuyo techo es de paja y las paredes de barro y madero, o de ladrillo, o de adove". Según Calcaño (§ 408) la palabra no es americanismo "ni siquiera en el sentido de 'choza' "; para él procede del it. rancio, y para probar que se trata de una antigua voz que significa "albergue de gitanos" recurre a ejemplos de Cervantes (La gitanilla) y de El lazarillo de Tormes. Granada no se interesa por la etimología; para él se trata de una "habitación tosca, regularmente fuera de poblado, con paredes de barro mezclado con bosta, techo de paja o de totora sostenido por horcones, y piso natural". Alvarado (Glosario bajo español, 406) registra dos acepciones: "cabaña, cobertizo", de uso general en España, y, en sentido despectivo: "casa ordinaria o de pobres costumbres"; aclara seguidamente que usada en plural "designa las ruinas o vestigios de una vivienda abandonada". Pagés, entre las varias acepciones que recoge, destaca: "choza o casa pobre con techumbre de ramas o paja, fuera de poblado", con cita de Bernardo de Valbuena y agrega esta sola calificación de americanismo: "granja donde se crían caballos y otros cuadrúpedos". Sejournant ofrece una ilustrativa serie de acepciones, pero ninguna recoge la significación americana. BoydBowmann recuerda que en Guanajuato "lejos de significar hacienda, finca, como en los EE. UU. el préstamo ranch, significa "casucha, casa pobre y humilde, fuera de los pueblos". En Costa Rica, en 1564, se aludía con rancho a "una vivienda pobre de indios"; en 1793, a una "vivienda rústica"; en la actualidad hablamos de una "vivienda rural hecha de cañas, con techo de palma o, en menor proporción de paja". 
RECIÉN. Sejournant es lacónico "Voyez recientemente". Pagés lo presenta como apócope de recientemente y aclara: "Úsase siempre antepuesto a los participios pasivos"; lo autoriza con citas de Bernardo de Valbuena y de Ruiz de Alarcón. Hay útil información en Keniston, 39, 74 y Kany, Syntax, 323 ss, 373 ss.

RESONDRAR. Inspirado ciertamente en Arona, Pagés la consagra como auténtico peruanismo. Dice "Perú: deshonrar, denostar".

SOROCHE. Granada remite directamente a puna, a cuya tercera acepción dedica esta explicación:

"Extraña y penosa ansiedad que en la travesía de la Cordillera de los Andes experimenta el viajero, por efecto de la rarefacción del aire de las alturas. Llámase también soroche". Lenz partirá de soroche en su explicación para concluir en puna; habla del "malestar que se siente a grandes alturas en la Cordillera por la rarefacción del aire = puna". Pagés alude al ámbito de difusión, la sitúa en la América meridional. Frederici recoge además las voces sorochi, sorocho. Middendorf propuso como étimo el quechua sorojchi "mineral que combina azufre con fierro y cobre" 47 .

SUCUCHO. Leemos en el Diccionario marítimo de Fernández de Navarrete (s.v. zocucho): "hueco que queda entre bao y bao y una tabla horizontal clavada en la capa inferior de estos a un mamparo o a la murada; regularmente está en los camarotes y sirve para guarda objetos de poco bulto". Unos defien-

47. Vásquez de Espinoza recuerda que en las funciones potosinas "beneficiaban el metal rico al qual echaban soroche, que es plomoso, para que mejorasse, derritiesse y fundiesse" (Compendio, № 1651). En el Mercurio Peruano, 1791, tomo I, 85-86 leemos: "Soroche: metales de plata con aspecto de plomo costroso, negro y reluciente". 
den una etimología quechua y la derivan de sucuchu 'cueva', 'guarida'; otros, como Cuervo, seguido por Calcaño, piensan que se trata de un galleguismo y se amparan en que Cuveiro Piñol la tiene registrada en su Diccionario gallego (Barcelona, 1786), cosa que no resulta indiferente para algunos (Fil. IV, 204-205). Alvarado le asigna el valor de "cárcel, mazmorra, calabozo" (Glos. bajo español, I, 437); Calcaño (\$ 423), el de 'cárcel', 'mazmorra', 'calabozo'; Calcaño, que no la cree americanismo, la tiene por "vivienda estrecha, rincón o covacha" y Granada registra "escondrijo, habitación ruin". Nadie repite a nadie pero la mayoría merodea por un área semántica afín. En algunos países alterna con socucho.

SUERTE. Pagés es categórico: "Perú: billete de lotería". Curiosa resulta la versión de Sejournant: "Se dit aussi d'un billet de lotérie".

TAMBO. Toda la información de Granada se concentra en estos datos: "Cuadra o corral de vacas, donde se expende leche. Sabido es que tambo significa en el Perú posada o mesón y que procede de la coz quichua tampu". Sejournant consigna: "Terme des Indes. Hotellerie, auberge". Peñalver aclara al usuario: "Mesón o venta (Es voz del Perú)". Domínguez glosa íntegramente esa definición. Pagés añade algunos datos: "del quichua tampu 'venta, posada, parador' " y la distribuye por Chile, Colombia, Ecuador y Perú. Es cierto que los cronistas de nuestra conquista usaron la palabra, pero con distintos significados: no es para discutirlo en este lugar $^{48}$. Alvar recoge varios testimonios, y entre ellos éste de Las Casas, Apologética, II, 602:

48. Carlos araníbar, en el glosario que acompaña a su ed. de la Relación de antigüedades, de Juan de Santa Cruz Pachacuti (FCE, 1995, s.v. tambo) ofrece una detallada exposición, fruto de confrontaciones entre varios textos de cronistas, y con énfasis en las significaciones militares de la voz. 
"Ciertas casas, que llamaban tambos, como mesones, de más de ciento y cincuenta pasos de luengo, muy anchas y espaciosas, limpias y aderezadas con muchas puertas y ventanas"

Marius Sala anota las expresiones del timbo al tambo frecuentes en Colombia, Cuba y Venezuela, con el valor de 'de la ceca a la meca', y tambo de tíos que, con el significado de "cualquier reunión desordenada y ruidosa" atribuye al Perú, que deberemos vincular con el significado de "reunión bulliciosa, especialmente de negros", señalada por Martha Hildebrant.

TOCUYO. La cita de Pagés es interesante: "(De Tocuyo, ciudad de Venezuela), Tela burda de algodón". Pero en el Glosario de voces indígenas de Venezuela, Lizaro Alvarado, s.v. tocuyo explica: "Lienzo de algodón ordinario que hacían en el Perú y el Ecuador para vestido de la gente común”. Y en su Glosario del bajo español, vol. I, 299, s.v. manta nos deja leer:

"tejidos ordinarios de algodón que. según la disposi-
ción de la urdimbre, se destinan a vestidos o a cal-
zado [...] Los primeros se fabrican en los Estados de
Occidente y la Cordillera [...] y deben ser de la misma
clase de la antigua tela llamada en gran parte de
América del Sur tocuyo".

Alvarado remite a la forma primitiva tucuyu 'zumo de yuca" "aplicada a una antigua población del Estado Anzoátegui" y perteneciente a la lengua cumanagota ${ }^{49}$.

TONGO. Pagés, con alusión a Argentina y Chile, postula: "Trampa que hace el pelotari, o el jinete en las carreras de

49. Alvarado acepta en realidad la tesis de Antonio Caulin, autor de la Historia corográfica, natural y evangélica de la Nueva Andalucia (Caracas, 1841). 
caballos, aceptando dinero para dejarse ganar". Admite para Chile la acepción 'sombrero hongo'. Hoy, en Argentina (Diccionario de Augsburgo), tongo: "Golpe que se da a alguien en la cabeza con los nudillos"; en el Uruguay (Diccionario de Ursula Kühl); coloquial y despectivo: "Procedimiento irregular por el que se beneficia a una persona en perjuicio de otras, haciendo prevalecer relaciones de amistad, parentesco o purtidismo político".

TRAPICHE. Para Peñalver, se trata de un "ingenio pequeño donde se fabrica el azúcar". Sejournant coincide: "Rouleaux qui servent à écraser les cannes de sucre dans le moulins à sucre". Pagés, con el respaldo de Góngora, 1611, y remitiéndose al lat. trapetes: "piedra de molino de aceite. Molino par extraer el jugo de algunas frutas de la tierra, como aceituna o caña de azúcar". No hay discusión sobre la etimología y García de Diego se remonta a trapetes (Dic. 6819) 'muela de molino de aceite' y se remonta al gr. iraphiron "machine à fouler le raisin, presser" (Ernout-Meillet, s.v. trapetum).

TRONCHA. Pagés sitúa en América meridional la acepción "tajada, loncha" y le asigna al Perú, en uso figurado, las significaciones de "breba, ganga, sinecura". Y s.v. tronchar nos ofrece dos acepciones: a) "partir o romper con violencia el tronco, tallo o ramas de un vegetal" y lo autoriza con un texto de Granada; b) "partir o romper con violencia cualquier cosa de figura parecida a la de un tronco o tallo". Su etimología: lat. trunculus 'tronquito' (García de Diego, Dic. Etim. 6890).

TUTUMA. Alvar registra además tucuma y tutuma por "Vasija hecha del fruto del totumo" y ofrece varias referencias tomadas de Cieza, Castellanos, Fray Pedro Simón, Jacinto de Carvajal, José Gumilla. Elegimos un texto de Pedro de Aguado:

"En el qual tiempo a de comer por tasa y dieta sola una totuma de maçamorra pequeña cada día [...] con una totuma de vino hecho con cierta caxcara de cedro" (Santa María, I, 793). 
Marius Sala consigna las expresiones venezolanas espada de totuma 'espada de taza' y boliviana pelar tutuma 'cortarse los cabellos al rape'. Agrega la variante totume y los derivados atotumarse 'atolondrarse' (Col.), destotumarse 'descalabrarse' (Mex.).

UTA. Pagés nos ofrece dos entradas: en la primera menciona una mariposa del Paraguay "que pica como mosquito y deja llaga de larga duración"; en la segunda dice: "insecto americano cuyas picaduras tienen iguales propiedades y es con frecuencia incurable", de donde sigue aludiendo ciertamente a la uta nuestra, ahora felizmente curable.

VINCHA. Granada (Vocab. riopl. I, 101-102, s.v. bincha) recoge tres acepciones: a) cinta que usan las niñas como adorno y para sujetar el cabello; b) pañuelo que los hombres del campo "llevan ceñido en torno a la cabeza" durante sus trabajos de campo en las estancias; c) "cinto usado del mismo modo y con el propio objeto que en los casos precedentes, por los indios e indias pampas, charrúas y de otras especialidades". Y entre los textos en que se ampara, trae uno de Santa Cruz Pachacuti. Pagés alude al quichua huincha y da para toda la zona andina: "Apretador o cinta o pañuelo con que se ciñe la cabeza o se sujeta el pelo". Ilustra con un texto de Lucio V. Mansilla que sirve para autorizar simultáneamente vincha o poncho. Malaret (BAAL, XIII, 341-342) da a vincha como precedente del araucano o quichua huincha y agrega que "es un peruanismo muy usado" y lo define como "la cinta de terciopelo, con que se sujetan el cabello las mujeres". El $R E W, 9341$, la deriva del lat. vinculu. Hans Ianner (Fil., I, 132) propone vincularla con el cat. vincle 'lazo', 'traba' y port brinco 'adorno para las orejas' y recuerda que el esp. brinco significaba "joya antigua que servía de adorno en las tocas", muy usada por los clásicos (lo que podemos confirmar acudiendo a Fontecha 54 y al Glosario de Jammes). Carlos J. Córdova nos recuerda que el padre Diego de Torres, en su 
Diccionario quichua ${ }^{50}$ contiene esta definición s.v. vincha: "Venda de lana con que atan la cabeza las indias". Alvar s.v. vincha remite a bincha, pero desgraciadamente no desarrolla explicación.

YAPA. Granada nos remite a llapa: "Donativo de corta entidad que el mercader hace al marchante en el acto de despachar la compra"; piensa que esta acepción es una aplicación vulgar de un término minero llapa. Ofrece en seguida otra acepción: "Parte reformada del lazo, hacia la punta, que es la que más trabaja y se desgasta con el roce de la argolla, y por donde se arma aquel al tiempo de lanzarlo. Es una añadidura del lazo que se renueva cuando conviene". Le asigna etimología quichua, yapana, admite que aceptemos yapa o llapa pero censura la forma ñapa que circulaba en Bogotá. Marius Sala registra también la grafía llapa y ñapa y ofrece variada noticia sobre las acepciones (y sus diversos matices) (208-209).

ZAMBO. Peñalver: "Dícese en Indias del hijo de negro y indias o al contrario". Domínguez acota: "nombre que recibe en América el descendiente de un negro y una mulata"; lo copia Pagés que únicamente agrega que se usa tanto como sustantivo y adjetivo. Resulta desconcertante que de las dos acepciones que ofrece Sejournant, la primera acoja la idea de 'estevado', pero la única referida a América reduce toda la información al mundo animal: "Animal sauvage \& déforme de l'Amérique: il est de la hauteur d'un gros dogue, a la tête semblable à celle du chuveal, \& sa peau est de diverses couleurs". ¿Quiere decir que, bien avanzado el XVIII, no había trascendido el significado americano? Otras sorpresas nos deparan los léxicos. Alvarado (Glosario del bajo español, I, 483) nos ofrece tres acepciones: a) siente que la palabra "tie-

50. El habla del Ecuador, s.v. se refiere al Arte y vocabulario de la lengua quichua de los Indios de el Perí, (Lima, Joseph de Contreras, 1700) publicado por el jesuita Diego de Torres Rubio. 
ne fuerza de aumentativo para ponderar la robusteza y apostura del hombre y sobre todo de la mujer de pueblo" y piensa que eso puede provenir sin duda "de la ordinaria robustez y pujanza peculiar a la raza cruzada de negro e indio"; b) "color rojo oscuro de los gallos"; c) recuerda la expresión zambo atravesado 'sujeto alevoso, mal intencionado'. En el Perú, como en Puerto Rico, se distingue entre 'zambo de indio' (negro cruzado con india) y 'zambo' (negro y mulata). Nazario recoge varias teorías: deriva del congo nzambu 'mono'; como derivación de zambaigo (o sambaigo, sambayo, zambahigo), "voz con que se llamó en Nueva España y en la América Central a tipos mezclados de indio y negro, que Ortiz interpreta como surgida de zambom con influjo de la voz mandinga sambango, aplicada al caballo de color bayo oscuro" y que Friderici (citado por Corominas) tiene como pronunciación aindiada o negras de zambo hijo según lo confirmaría la grafía zambahigo. Nazario piensa en una forma recortada de mozambique "a través de la etapa de moçambo, que se da en Brasil; como ampliación del sentido de la palabra española zambo 'pernituerto', fundamentada esta idea en un alegado desarrollo distinto de las piernas del negro 'de pantorrillas más flacas' "y cita un ejemplo de Quevedo: "salió un mulatazo [...] zambo de piernas a lo águila imperial" (El elemento afronegroide en el español de Puerto Rico, San Juan de Pto. Rico, 1961, 361$362)$. En tanto en Costa Rica desde 1736 se alude con zambo al cruce de negro e india o negro y mulata, y en el Uruguay actual a la 'mentira' y el 'embuste', comprobamos que en el Ecuador actual ha perdido la connotación ofensiva que parece haber tenido en la Colonia, sin duda "por la división racial y el régimen de esclavitud" o por "la mala reputación de los zambos".

ZAPALLO. Alvar cita el hermoso texto del padre Acosta (Hist. nat. IV, XX, 113-114), del que rescato este fragmento:

"Pues las calabazas de Indias son otra monstruosidad de su grandeza y vicio con que se crían, especialmente las que son propias de las tierra, que allá 
llaman zapallos, cuya carne sirve para comer, especialmente en cuaresma, cocida o guisada".

Marius Sala registra las grafías Sapallo, zapayo, zapalla, zapulla y acoge la expresión argentina andar como zapallo en un zarro "andar de un lado para el otro, siempre a los tumbos y golpes" y la boliviana todo guías nada zapallo "dícese de la persona que afana mucho y hace poco".

\section{$* * *$}

Un aprovechamiento esperable de esta nota (y de cuantas pudiera originar todavía el libro de Martha Hildebrant) ha de tonificar el campo de nuestros estudios lexicológicos y avivar el interés por el campo lexicográfico. Hay muchas tareas para la filología que aun no hemos emprendido. Enumero al azar para quienes quieran estudiar las voces que han caído en desuso y analizar, apoyados en severo análisis lexicológico, aquellas que las están reemplazando; para quienes deseen analizar aquellas voces que han modificado su significación y averiguar las causas y caminos que originaron el nuevo significado. El que quiere trabajar en una perspectiva diacrónica puede dedicarse a estudiar las palabras que, estando vigentes en 1969, no fueron consideradas en el libro (teniendo en cuenta, por cierto, que no era intención de $\mathrm{MH}$ redactar un diccionario), o las que, estando vigentes en 1994, no fueron tomadas en cuenta (con la misma salvedad que para el caso anterior). Una atrayente tarea espera a quienes se interesen en los indigenismos: mucho ha progresado la bibliografía en relación con el taíno y el nahuatl, y esperamos que sobre los quechuismos pueda realizarse una investigación como la que M. L. Wagner postulaba para los aztequismos. Claro es que todas estas sugerencias miran al conjunto. Pero la lectura de Peruanismos puede auspiciar inquietudes de otra índole orientadas hacia una palabra determinada: los estudios de Harri Meier, Kurt Baldinger, Fritz Kruger, Joan Corominas y Jakov Malkiel, entre otros ilustres investigadores, estuvieron consagrados a una voz determinada. Entre las 
voces acá reunidas por $\mathrm{MH}$ entreveo investigaciones específicas que convidan a monografias importantes: las atrayentes historias de guapo, poncho y zambo, donde el sólo planteamiento del 'estado de la cuestión' implicaría un avance; los cambios de significación que fue sufriendo camote ('dulce', 'amor', 'simpatía con cariño', 'sabor') que deberán ilustrarse con textos que nos inviten a arriesgar la aventura de un diccionario peruano de autoridades; el inquietante estudio a que convida la historia de dolama (que ha de llevarnos desde el mundo de las caballerizas y la veterinaria hasta el de los dolores corporales y la medicina); y, por último, el nunca rematado inventario de los cambios de significación por los que fue atravesando broma, con los textos que respalden sus usos de 'gusano que horada la piedra', 'pesadez', 'molestia', 'contraste'. Y las sugerencias no cierran la lista sino que la dejan en suspenso.

Esta invitación a enrolarse en tamaña tarea es un modo de ayudarnos a perfeccionar el conocimiento del español en América, tema sobre el cual el progreso ha sido extraordinario en los últimos años, tanto en la perspectiva sincrónica como en la diacrónica. Debemos destacar cuánto ha iluminado el panorama lo investigado en torno de la América negra: el conocimiento de la influencia africana en las colonias portuguesas y en Cartagena ha iluminado aspectos hasta entonces oscuros del español caribeño y ha aclarado algunas nebulosas sobre el espan̄ol rioplatense. Se ha contribuido así a precisar la historia de muchas voces vinculadas con la hora colonial y a comprender muchas otras relacionadas con la población negra ${ }^{51}$. El gran tema del siglo XXI ha de ser cier-

51. Me remito a los trabajos de Matthias Perl y Armin Schwegler (eds.), América Negra: panorama actual de los estudios lingūísticos sobre variedades hispanas, poruguesas y criollas, Frankfurt, Iberoamericana, 1998; y los de Angela Bartens, Die ibero-romanisch-basierten Kreolsprachen, Frankfurt, Peter Lang, 1995 y Der kreolische Sprachraum, Heisinki, Suomalainen Tiedeakatemia, 1996, para citar algunos de los más significativos. 
tamente el español en América, con lo que habremos superado confusas discusiones en que estuvo largo tiempo empeñada la filología hispánica y de las que nos ha permitido ir saliendo la incesante investigación de eminentes maestros europeos e hispanoamericanos. Si un libro como Peruanismos suscita este cúmulo de reflexiones se justifica que lo celebremos como una obra clásica y moderna, que todavía mantiene el vigor y la solidez de su edición primera. 